\title{
Podophyllotoxin: History, Recent Advances and Future Prospects
}

\author{
Zinnia Shah ${ }^{1}\left(\mathbb{D}\right.$, Umar Farooq Gohar ${ }^{1}$, Iffat Jamshed ${ }^{1}$, Aamir Mushtaq ${ }^{2}$ (D) , Hamid Mukhtar ${ }^{1}$ (D), \\ Muhammad Zia-UI-Haq ${ }^{3, *}$, Sebastian Ionut Toma ${ }^{4, *}$, Rosana Manea ${ }^{4, *}$, Marius Moga ${ }^{4}$ and Bianca Popovici 4 \\ 1 Institute of Industrial Biotechnology (IIB), Government College University, Lahore 54000, Pakistan; \\ syedazinniashah@gmail.com (Z.S.); dr.mufgohar@gcu.edu.pk (U.F.G.); buttiffat804@gmail.com (I.J.); \\ hamidmukhtar@gcu.edu.pk (H.M.) \\ 2 Gulab Devi Institute of Pharmacy, Gulab Devi Educational Complex, Lahore 54000, Pakistan; \\ aamir_mushtaq@hotmail.com \\ 3 Office of Research, Innovation \& Commercialization, Lahore College for Women University, \\ Lahore 54000, Pakistan \\ 4 Faculty of Medicine, Transilvania University of Brasov, 500036 Brasov, Romania; moga.og@gmail.com (M.M.); \\ biancadr@yahoo.com (B.P.) \\ * Correspondence: zia.haq@lcwu.edu.pk (M.Z.-U.-H.); toma.ionut@unitbv.ro (S.I.T.); \\ rosana.manea@unitbv.ro (R.M.)
}

check for updates

Citation: Shah, Z.; Gohar, U.F.; Jamshed, I.; Mushtaq, A.; Mukhtar, H.; Zia-UI-Haq, M.; Toma, S.I.; Manea, R.; Moga, M.; Popovici, B. Podophyllotoxin: History, Recent Advances and Future Prospects. Biomolecules 2021, 11, 603. https://doi.org/10.3390/biom 11040603

Academic Editor: Diaa Youssef

Received: 9 March 2021

Accepted: 14 April 2021

Published: 19 April 2021

Publisher's Note: MDPI stays neutral with regard to jurisdictional claims in published maps and institutional affiliations.

Copyright: (c) 2021 by the authors. Licensee MDPI, Basel, Switzerland. This article is an open access article distributed under the terms and conditions of the Creative Commons Attribution (CC BY) license (https:// creativecommons.org/licenses/by/ $4.0 /)$.

\begin{abstract}
Podophyllotoxin, along with its various derivatives and congeners are widely recognized as broad-spectrum pharmacologically active compounds. Etoposide, for instance, is the frontline chemotherapeutic drug used against various cancers due to its superior anticancer activity. It has recently been redeveloped for the purpose of treating cytokine storm in COVID-19 patients. Podophyllotoxin and its naturally occurring congeners have low bioavailability and almost all these initially discovered compounds cause systemic toxicity and development of drug resistance. Moreover, the production of synthetic derivatives that could suffice for the clinical limitations of these naturally occurring compounds is not economically feasible. These challenges demanded continuous devotions towards improving the druggability of these drugs and continue to seek structure-optimization strategies. The discovery of renewable sources including microbial origin for podophyllotoxin is another possible approach. This review focuses on the exigency of innovation and research required in the global R\&D and pharmaceutical industry for podophyllotoxin and related compounds based on recent scientific findings and market predictions.
\end{abstract}

Keywords: novel biomolecules; antitumor phytochemical; podophyllotoxins; chemotherapy; COVID-19; cytokine storm

\section{Introduction}

Podophyllotoxin is an aryltetralin-type lignan isolated from species of Podophyllum [1,2]. Two most common sources are the rhizomes of Podophyllum peltatum (American mayapple) and Sinopodophyllum hexandrum Royle (Barberry family) [1,3]. These perennial herbs are distributed widely across the Himalayan region and Western China [4-7]. Plants with high podophyllotoxin or podophyllotoxin-analogues' content have been extensively used in traditional medicine since a long time in different cultures [8-11]. This remarkable molecule was first isolated in 1880 by Podwyssotzki [12-15], while it had already been described as early as in 1753 by Linnaeus [16]. Due to its remarkable biological activity, podophyllotoxin has remained a subject of various investigations ever since. It is mainly obtained from the alcohol-soluble fraction of Podophyllum species, called podophyllin-a bitter tasting resin.

The podophyllotoxin extract has been documented for its use as a laxative, and as a remedy for various medical complications such as gonorrhea, tuberculosis, menstrual disorders, psoriasis, dropsy, cough, syphilis and venereal warts [8-11]. The podophyllotoxinfamily is now confirmed to elicit various curative properties such as mitotoxic, neurotoxic, 
insecticidal, antimicrobial, anti-inflammatory, antispasmogenic, hypolipidemic, immunosuppressive, antioxidative, analgesic and cathartic activities [17]. Initial studies reporting its pronounced activity against cancer cells established greater interest in its antimitotic efficacy. The clinical practicality of podophyllotoxin was, however, largely tampered because of its undesirable secondary effects such as gastrointestinal toxicity, neurotoxicity, hair-loss, and bone marrow suppression, etc., which led to the finding of less-toxic derivatives or analogues. These molecules have since become a structural base for the development of new therapeutic agents.

Podophyllotoxin $\left(\mathrm{C}_{22} \mathrm{H}_{22} \mathrm{O}_{8}\right)$ is a selective cyclolignan whose structure was first elucidated in 1930s. Extensive structural modifications of podophyllotoxin have culminated to eventually discover clinically viable anticancer drugs, namely; etiposide, teniposide [18-25] and etopophos [26], but it was not until twenty years after the discovery of these viable derivatives that their mechanism of action was understood. Podophyllotoxins were recognized to interact with the DNA and its replication process to carry out their antimitotic effects. Etiposide, for instance, inhibits DNA topoisomerase II (dnaTII) and causes cell cycle arrest in the S-phase. Podophyllotoxin is also known to prevent cell growth through inhibiting the polymerization of tubulin and thus subdue the configuration of mitotic spindles [26]. The therapeutic use of these drugs is however, in fact, hindered by myelosuppression, development of drug-resistance and their cytotoxic activity towards normal body cells. On these accounts, the synthesis of new potent podophyllotoxin-derivatives such as NK-611 [27], NPF [28], GL-311 [29], TOP-53 [30], F14512 [26], azatoxin, etc., is a continuing concern - structures of some of these derivatives are shown in Figure 1. These have thence opened a window for virtual designing of unlimited podophyllotoxin-derivatives geared at improving clinical efficacy. These studies necessitate reviewing all the recent advancement made on podophyllotoxin. Furthermore, the extinction of podophyllotoxin plant sources shifted the focus towards source alternatives, which includes the manipulation of microbes for the purpose. This review is aimed at providing an insight to podophyllotoxin research and hence helps delineate further investigations, which are needed in this field.
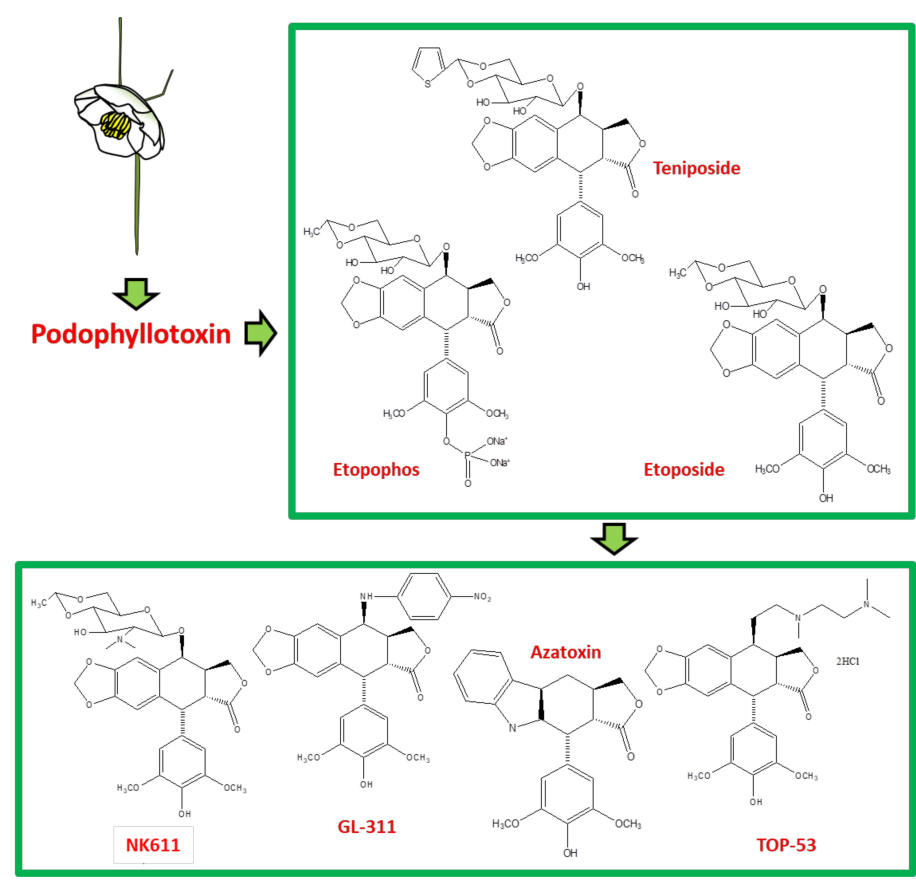

Figure 1. The sequential discovery of podophyllotoxin-group of drugs. FDA approved anticancer drugs etoposide, teniposide and etopophos were derived from the parent compound podophyllotoxin, which was originally extracted from mayapple plant as a curative for various diseases. As the side-effects for podophyllotoxin and its primary derivatives became evident, less toxic derivatives such as TOP-53, NK611, GL-331, azatoxin and various others were designed and synthesized. 


\section{Structural Characteristics of Podophyllotoxin}

Podophyllotoxin has a five-ring system (ABCDE) having four chiral centers (C1-C4) in a row-Figure 2. There are five important structural characteristics of most podophyllotoxin species: (1) a tetracyclic group going from dioxole ring (A) to the lactone ring (D); (2) four oxygen atoms located at the functional groups lactone, methoxys, secondary alcohol and oxoles; (3) ring E with alpha-configuration located at position 1; (4) four asymmetrical adjacent centers and (5) the unique stereochemical properties of $\mathrm{C} 4$ define the molecules mechanism of action [31,32]. Studies have revealed, rational modification at $C 4$ can improve the molecule's topoisomerase II inhibitory activity, drug resistance profile, water solubility and antimitotic activities [33]. The lactone ring is known to exhibit transconfiguration, which easily epimerizes in low basic conditions [32].

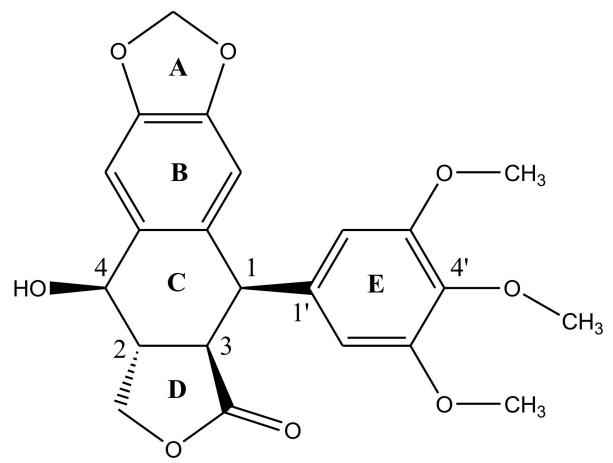

Figure 2. Structural representation of podophyllotoxin. The structure is constituted of 4 aromatic rings $A, B, C$ and $D$ arranged in an almost planar system whereas ring $E$ is attached quasi-axially at $\mathrm{C} 4$ of ring $\mathrm{C}$.

\section{Derivatives, Analogues and Hybrids of Podophyllotoxin}

Derivatives of this multifaceted molecule are synthesized as properties of its four rings. Ring A, for instance is not essential for the exhibition of antimitotic activity, and aromatization of ring $\mathrm{C}$ may cause displacement of axially positioned ring E-leading to a loss of cytotoxic property. Structural diversity hence brings many attractive medicinal properties and a comprehensive insight to the molecule's mechanism of action. These derivatives were first introduced by Schreier through selective cleavage of ring A to produce a 6, 7-dihydroxy derivative (compound $\mathrm{A}$ ), which was further methylated with diazomethane to produce yet another derivative (compound B) shown in Figure 3 [34]. Schreier's methods were later on slightly modified to produce a large group of podophyllotoxin derivativescompound I-XXfrom compound C, Figure 3. However, the structural modifications are not alone to contribute towards the novelty of the derivatives, instead, changes in the chemical skeleton of podophyllotoxin cyclo-lignan add particularity to each individual derivative.<smiles>COc1cc([C@H]2c3cc(O)c(O)cc3[C@@H](O)[C@H]3COC(=O)[C@@H]23)cc(OC)c1OC</smiles>

Compound A

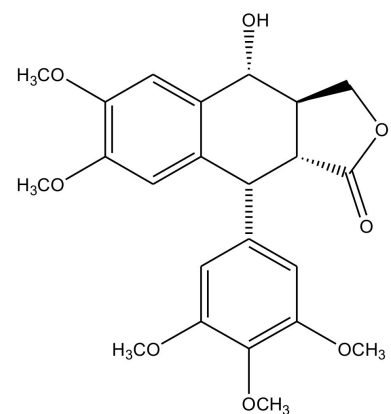

Compound B

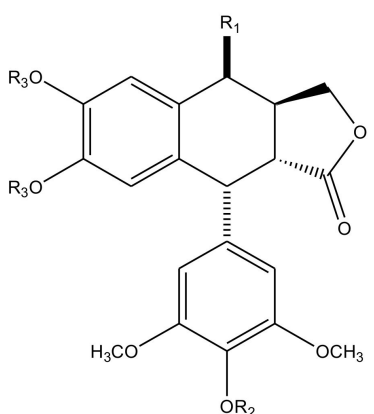

Compound C

Figure 3. Cont. 
<smiles>COc1cc([C@H]2c3cc(O)c(O)cc3[C@@H](Nc3ccccc3)[C@H]3COC(=O)[C@@H]23)cc(OC)c1OC</smiles>

Compound I<smiles>COc1cc([C@H]2c3cc(O)c(O)cc3[C@@H](Nc3ccc(C#N)cc3)[C@H]3COC(=O)[C@@H]23)cc(OC)c1OC</smiles>

Compound IV<smiles>COc1cc([C@H]2c3cc(O)c(O)cc3[C@@H](Nc3ccccc3)[C@H]3COC(=O)[C@@H]23)cc(OC)c1O</smiles>

Compound VII<smiles>CCOc1c(OC)cc([C@H]2c3cc(O)c(O)cc3[C@@H](Nc3ccc([N+](=O)[O-])cc3)[C@H]3COC(=O)[C@@H]23)cc1OC</smiles><smiles>Nc1ccc(F)cc1</smiles><smiles>COc1cc([C@@H]2c3cc(O)c(O)cc3[C@@H](C)[C@@H]3COC(=O)[C@H]32)cc(OC)c1OC</smiles><smiles>COc1cc([C@H]2c3cc(O)c(O)cc3[C@@H](Nc3ccc([N+](=O)[O-])cc3)[C@H]3COC(=O)[C@@H]23)cc(O)c1O</smiles>

Compound VIII<smiles>CCOC(=O)c1ccc(N[C@H]2c3cc(O)c(O)cc3[C@@H](c3cc(OC)c(OC)c(OC)c3)[C@H]3COC(=O)[C@@H]23)cc1</smiles>

Compound III<smiles>Nc1ccc(O)cc1</smiles><smiles>CN[C@@H]1c2cc(O)c(O)cc2[C@@H](c2cc(OC)c(OC)c(OC)c2)[C@@H]2C(=O)OC[C@H]12</smiles>

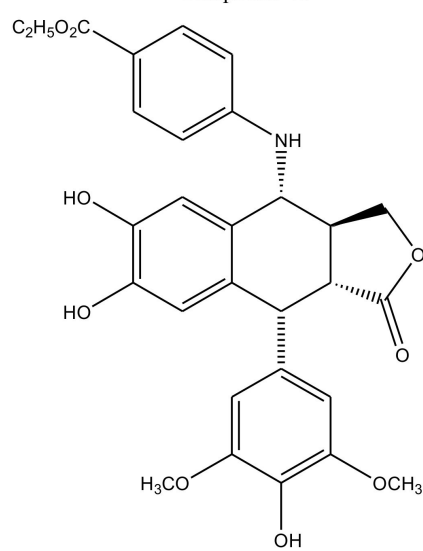

Compound IX

Figure 3. Cont. 
<smiles>COc1cc([C@H]2c3cc(O)c(O)cc3[C@@H](Nc3ccc(C#N)cc3)[C@H]3COC(=O)[C@@H]23)cc(OC)c1O</smiles>

Compound X<smiles>CNc1ccccc1</smiles><smiles>COc1cc2c(cc1OC)[C@@H](c1cc(OC)c(OC)c(OC)c1)[C@H]1C(=O)OC[C@H]1[C@H]2C</smiles>

Compound XIII<smiles>COc1cc2c(cc1OC)[C@@H](c1cc(OC)c(OC)c(OC)c1)[C@H]1C(=O)OC[C@H]1[C@H]2Nc1ccc(C#N)cc1</smiles>

Compound XVI<smiles>COc1cc([C@H]2c3cc(O)c(O)cc3[C@@H](Nc3ccc(F)cc3)[C@H]3COC(=O)[C@@H]23)cc(OC)c1O</smiles>

Compound XI<smiles>COc1cc2c(cc1OC)[C@@H](c1cc(OC)c(OC)c(OC)c1)[C@H]1C(=O)OC[C@H]1[C@H]2Nc1ccc([N+](=O)[O-])cc1</smiles>

Compound XIV<smiles>COc1cc2c(cc1OC)[C@@H](c1cc(OC)c(OC)c(OC)c1)[C@H]1C(=O)OC[C@H]1[C@H]2Nc1ccc(F)cc1</smiles><smiles>COc1cc([C@H]2c3cc(O)c(O)cc3[C@@H](Nc3cccc(O)c3)[C@H]3COC(=O)[C@@H]23)cc(OC)c1O</smiles>

Compound XII<smiles>COC(=O)c1ccc(N[C@H]2c3cc(OC)c(OC)cc3[C@@H](c3cc(OC)c(OC)c(OC)c3)[C@H]3C(=O)OC[C@@H]23)cc1</smiles>

Compound XV<smiles>CCOC(=O)c1ccc(N[C@H]2c3cc(OC)c(OC)cc3[C@@H](c3cc(OC)c(O)c(OC)c3)[C@H]3COC(=O)[C@@H]23)cc1</smiles>

Compound XVIII

Figure 3. Cont. 

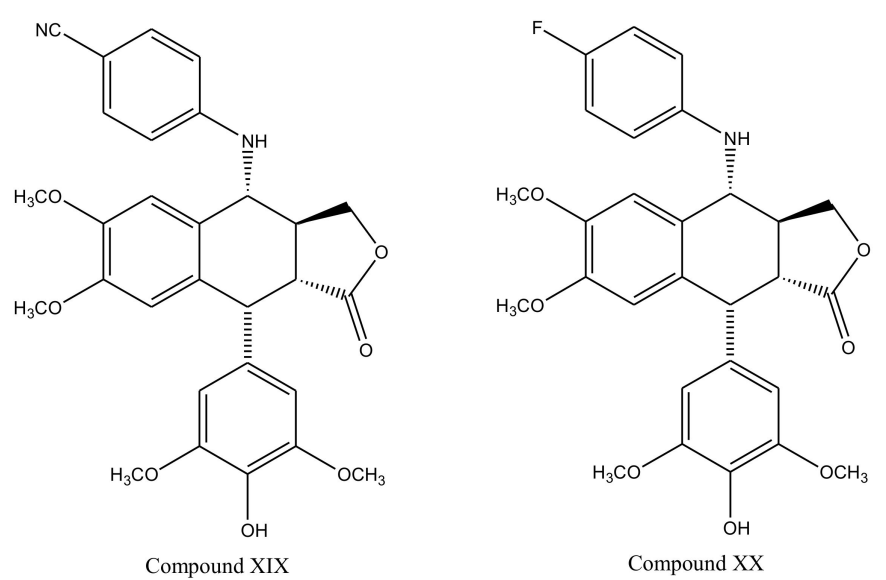

Figure 3. Podophyllotoxin derivatives produced by selective cleavage of ring A through Schreier's method and the modified-Schreier method. These ring-A-open compounds, however, appeared biologically less active than podophyllotoxin itself.

With slight modifications in the podophyllotoxin skeleton, the ring-A-open compounds appeared biologically less active than podophyllotoxin itself [35]; functional studies indicate that an intact A-ring system is important for the compounds' DNA topoisomerase II (dtopII) inhibiting activity. Based on these findings, three crucially significant domains in the parent pharmacophore model were reported [36]. Modifications at these domains further revealed the unexplored potential of novel clinically applicable derivatives (shown in Figure 4)with a mechanism of action distinct to that of the previously well-established derivative; etiposide [37]. The paucity of studies on B-ring modifications in podophyllotoxin led the investigation of $\alpha$-peltatin and $\beta$-peltatin. These two compounds (Figure 5) exhibited significant antiviral and antitumor activities. In order to investigate the influence of B-ring substitutions and modifications, a series of ester- and ether-derivatives of both structures were prepared by various researchers but were reported to be biologically less active than their parent compounds [38-43].<smiles>COc1cc([C@H]2c3cc4nc5cc6ccccc6cc5nc4cc3[C@@H](O)[C@H]3COC(=O)[C@@H]23)cc(OC)c1OC</smiles>

Compond XXI<smiles>COc1cc([C@H]2c3cc4nc5ccccc5nc4cc3[C@@H](Nc3ccc([N+](=O)[O-])cc3)[C@H]3COC(=O)[C@@H]23)cc(OC)c1O</smiles>

Compound XXII

Figure 4. Cont. 
<smiles>COc1cc([C@H]2c3cc4nc5cc(Cl)c(Cl)cc5nc4cc3[C@@H](Nc3ccc([N+](=O)[O-])cc3)[C@H]3COC(=O)[C@@H]23)cc(OC)c1O</smiles>

Compound XXIII<smiles>COc1cc([C@H]2c3cc4nc5ccccc5nc4cc3[C@@H](O)[C@H]3COC(=O)[C@@H]23)cc(OC)c1OC</smiles>

Compond XXV<smiles>O=C1OCC2c3cc4nc5cc6ccccc6cc5nc4cc3[C@H](Nc3ccc(O)cc3)c3cc4nc5cc6ccccc6cc5nc4cc3C12</smiles>

Compound XXIV<smiles>COc1cc([C@H]2c3cc4nc5cc(Cl)c(Cl)cc5nc4cc3[C@@H](O)[C@H]3COC(=O)[C@@H]23)cc(OC)c1OC</smiles>

Compond XXVI

Figure 4. The significance of ring A for biological functionality of podophyllotoxin and its derivatives introduced three crucially significant domains in the parent pharmacophore model. Modifying these domains provided a number of new derivatives as shown (Compound XX1-XXVI). These compounds show distinct mechanism of actions in comparison to the previously discovered podophyllotoxin derivatives.<smiles>COc1cc([C@H]2c3cc4c(c(O)c3C[C@H]3COC(=O)[C@H]23)OCO4)cc(OC)c1O</smiles>

alpha-peltatin<smiles>COc1cc([C@H]2c3cc4c(c(O)c3C[C@H]3COC(=O)[C@H]23)OCO4)cc(OC)c1OC</smiles>

beta-peltatin

Figure 5. Cont. 


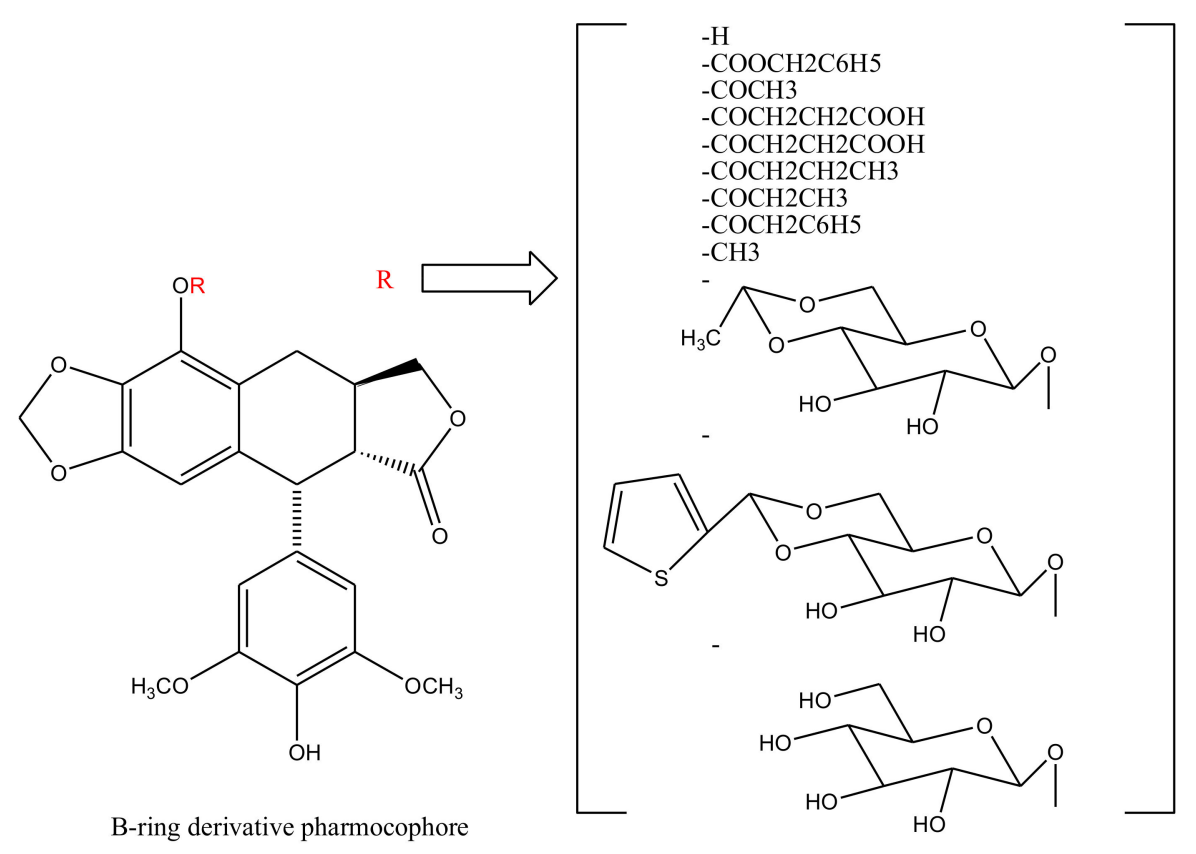

Figure 5. Structures of alpha-peltatin and beta-peltatin. These two B-ring modified podophyllotoxin derivatives are known to exhibit significant antiviral and antitumor activities. The B-ring modified pharmacophore was identified from these compounds and was taken further to synthesize more derivatives—as shown bracketed—none of which elicited any clinical efficacy.

Several C-ring modified podophyllotoxin analogues have also been subjected to extensive research. Unlike the two natural C-aromatized lignans; justicidin A and diphyllin; the many synthetic $\mathrm{C}$-ring aromatized compounds were prepared but reported to have no cytotoxic activities. This observation proposed that the axial E-ring conformation was lost during synthetic preparations. The loss of the axial E-ring conformation is now known to be directly linked to the loss of molecule's cytotoxic and dtopII inhibiting activity [44]. Notably, however, delactonized analogues of podophyllotoxin-apopicropodophyllotoxin; and its beta-isomer- $\beta$-apopicropodophyllotoxin give strong antimitotic activities, otherwise indicating the untrammelled antimitotic potential of podophyllotoxin-like compounds in the absence of the lactone ring [45-47]. The antitumor activity of podophyllotoxin and its derivatives is mainly due to the ability to inhibit tubulin polymerization [48], which is a property of the axially placed E-ring. The cis-fused lactone rings, however, modulating its selectivity from tubulin to IGF-1 (insulin- like growth factor I) receptor to trigger cell death [49-51].

Transfused $\gamma$-lactone $\mathrm{D}$ ring is also strict requirement for podophyllotoxin's antitumor activity. Since it is susceptible to isomerization, the opening of this lactone ring is undesirable for it limits the physiological lifetime of these compounds and their biological effectiveness as well. A series of delactonized D-ring derivatives were prepared [52-57] and studied by various researchers, most of which were found to be less cytotoxic than the parent compound itself. However, an ethyl hydrazide derivative (Figure 6) was found to retain its clinical efficacy but was discontinued due to severe adverse aftereffects [58]. Studies that later discovered immunosuppressive ability of these derivatives were attempted to revive D-ring modified podophyllotoxin — antitumor drug preparations $[59,60]$. $4^{\prime}$-d- $\beta$-DMEP ( $4^{\prime}$-d- $\beta$-Demethylepipodophyllotoxin) is a natural lignin, which is used in chemotherapy as an aglycon of etoposide [61,62]. $4^{\prime}-\mathrm{d}-\alpha$-DMEP is a novel biological derivative of $4^{\prime}$ - $\mathrm{d}$ - $\beta$ DMEP reported by Jia et al. (2020), which has a higher antitumor activity [63]. 
<smiles>CCNC(=O)[C@@H]1[C@@H](CO)[C@H](O)c2cc3c(cc2[C@H]1c1cc(OC)c(OC)c(OC)c1)OCO3</smiles>

Figure 6. A series of delactonized D-ring derivatives have remained the focus of many studies. An ethyl hydrazide derivative, drawn here, was reportedly the only D-ring modified compound, which showed clinical efficacy, but was discontinued after occurrence of various cases of severe side-effects related to its use.

E-ring modifications have only actually focused on enhancing E-ring's involvement in the cytotoxic mechanism of the compound. With an increased access to the compounds' physicochemical behavior, a variety of exciting derivatives with successful clinical application have been developed, such as those shown in Figure 7 [64,65].

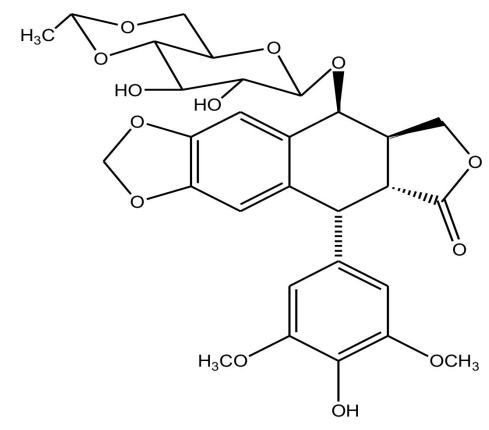

Etoposide<smiles>COc1cc([C@H]2c3cc4c(cc3[C@@H](Nc3ccc([N+](=O)[O-])cc3)[C@H]3COC(=O)[C@H]23)OCO4)cc(OC)c1O</smiles>

GL331

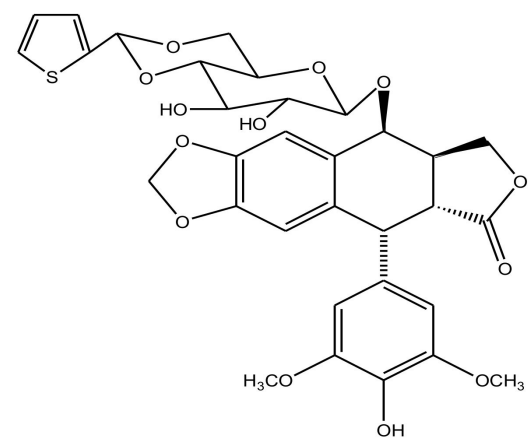

Teniposide<smiles>COc1cc([C@H]2C3Nc4ccccc4[C@H]3C[C@H]3COC(=O)[C@@H]23)cc(OC)c1O</smiles>

Azatoxin

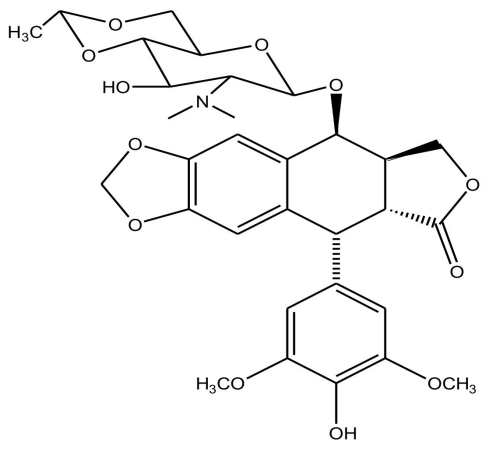

NK61 1<smiles></smiles>

TOP-53

Figure 7. Cont. 


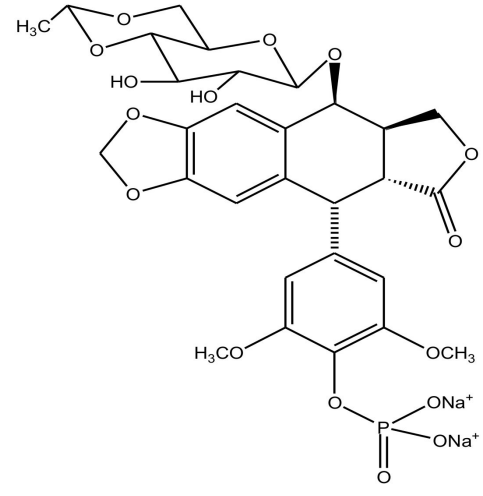

Etopophos<smiles>COc1cc([C@H]2c3cc4c(cc3[C@@H](O[C@H]3O[C@@H]5CO[C@@H](C)OC5[C@H](OC(=O)COc5c(F)c(F)c(F)c(F)c5F)[C@@H]3O[C@H](O)COc3c(F)c(F)c(F)c(F)c3F)[C@H]3COC(=O)[C@@H]23)OCO4)cc(OC)c1OP(=O)(O)O</smiles>

Tafluposide<smiles>COc1cc([C@H]2c3cc4c(cc3C=C(C=O)[C@@H]2C(C)=O)OCO4)cc(OC)c1OC</smiles>

Podophyllic aldehyde<smiles>CC/N=C/C1=Cc2cc3c(cc2[C@@H](c2cc(OC)c(OC)c(OC)c2)[C@H]1C(=O)OCCCCCCn1cnc2c(Cl)ncnc21)OCO3</smiles>

Figure 7. The figure shows structural illustrations of E-ring modified derivatives much of which have proved to be clinically significant.

\section{Plant Sources of Podophyllotoxin}

A variety of plant species belonging to approximately over 60 vascular families have been reported as viable sources of podophyllotoxin, which includes genera other than the genus Podophyllum, such as Diphylleia and Dysosma (beriberidaceae), Haplophyllum (Rutaceae), Thuja, Jeffersonia, Anthriscus (Apiaceae), Callitris and Thujopsis (Cupresceae), Hernandia (Hernandiaceae), Nepeta and Thymus (Labiaceae), Catharanthus (Apocynaceae), Teucrium, Hyptis (Verbenaceae), Commiphora (Burseraceae), Polygala (Polygalaceae), Linun (Linaceae), Juniperus and Cassia (Fabaceae) $[17,26]$. Podophyllotoxin is found accumulated mostly in the roots and rhizomes of these plants but have also been detected in their stems, roots, seeds, fruits, leaves, woody parts and, in some cases, from the associated endophytic microorganisms. However, Podophyllum hexandrum Royle has been reported to contain higher amounts of podophyllotoxin (4.3\%) compared to other podophyllotoxin producing plant species [66]. The various podophyllotoxin producing plant species have been tabulated below (Table 1). 
Table 1. Various plants from different plant families, which are well reported as sources of podophyllotoxin.

\begin{tabular}{|c|c|c|c|c|}
\hline S. No. & $\begin{array}{l}\text { Family; } \\
\text { Plant(s) }\end{array}$ & Part Used & Derivative & Ref. \\
\hline 1 & $\begin{array}{c}\text { Apiaceae; } \\
\text { Chaerophyllum aurium }\end{array}$ & $\begin{array}{c}\text { Extract of } \\
\text { subaerial part }\end{array}$ & $\begin{array}{l}\text { Deoxy podorhizone and } \\
\text { deoxypodophyllotoxin }\end{array}$ & [67] \\
\hline 2 & $\begin{array}{c}\text { Acanthaceae; } \\
\text { Justicia heterocarpa }\end{array}$ & $\begin{array}{l}\text { Extract of } \\
\text { aerial part }\end{array}$ & Podophyllotoxin lignan & [68] \\
\hline 3 & $\begin{array}{c}\text { Berberidaceae; } \\
\text { Jeffersonia diphylla, } \\
\text { Dysosma pleiantha, } \\
\text { Dysosma versipellis var. tomentosa, } \\
\text { Dysosma versipellis }\end{array}$ & $\begin{array}{l}\text { Extract of root, } \\
\text { Culture of Callus, }\end{array}$ & $\begin{array}{l}\text { Podophyllotoxin, kaempferol and } \\
\text { quercetin, Podophyllotoxin } \\
\text { derivatives, } \\
\text { 4-demethylisopodophyllotoxin }\end{array}$ & [69-73] \\
\hline 4 & $\begin{array}{l}\text { Burseraceae; } \\
\text { C. incisa } \\
\text { B. permollis } \\
\text { B. fagaroides } \\
\text { B. microphylla } \\
\text { B. konkinensis }\end{array}$ & $\begin{array}{l}\text { Resin, Stem bark, } \\
\text { Exudate, Stem, } \\
\text { Extract of root }\end{array}$ & $\begin{array}{l}\text { Derivatives of podophyllotoxin, } \\
\text { Deoxypodophyllotoxin, } \\
\text { 4-demethyldeoxypodophyllotoxin }\end{array}$ & [74-78] \\
\hline 5 & $\begin{array}{l}\text { Broginaceae; } \\
\text { L. erythrorhizon }\end{array}$ & $\begin{array}{l}\text { Extract of } \\
\text { needle leaf }\end{array}$ & Podophyllotoxin and derivatives & [79] \\
\hline 6 & $\begin{array}{l}\text { Cupressaceae; } \\
\text { J. sabina } \\
\text { J. virginia } \\
\text { J. conferta } \\
\text { C. preissii } \\
\text { J. depressa } \\
\text { C. rhomboidea } \\
\text { J. virginiana } \\
\text { J. chinensis } \\
\text { J. horizontalis } \\
\text { J. davurica } \\
\text { C. endlicher } \\
\text { J. thurifera } \\
\text { C. drummondii } \\
\text { C. intratropica } \\
\text { J. squamata } \\
\text { J. chinensis } \\
\text { C. collumelaris } \\
\text { J. scopulorum } \\
\text { J. lucayana } \\
\text { J. virginiana } \\
\text { J. silicicola } \\
\text { J. viriginia } \\
\text { T. occidentalis }\end{array}$ & $\begin{array}{l}\text { Extract of needle } \\
\text { leaf, Culture of } \\
\text { suspension, culture } \\
\text { of callus, needle } \\
\text { leaf aqueous } \\
\text { suspension, extract } \\
\text { of needle leaf, } \\
\text { Extract of stem, } \\
\text { Extract of wood, } \\
\text { Aerial part, Twig } \\
\text { and extract of } \\
\text { needle leaf }\end{array}$ & $\begin{array}{c}\text { Podophyllotoxin and derivatives, } \\
\text { Deoxypodophyllotoxin, } \\
\text { 5-methoxypodophyllotoxin }\end{array}$ & [79-92] \\
\hline 7 & $\begin{array}{l}\text { Linaceae; } \\
\text { L. perenne } \\
\text { L. scabrellum } \\
\text { L. thracicum spp. } \\
\text { L. capatitum } \\
\text { L. elegans } \\
\text { L. austriacum } \\
\text { L. arboreum } \\
\text { L. hirsutum } \\
\text { L. usitatissimum } \\
\text { L. scabrellum } \\
\text { L. strictum spp. } \\
\text { L. album } \\
\text { L. flavum } \\
\text { L. mucronatum spp. } \\
\text { L. persicum } \\
\text { L. nodiflorum } \\
\text { L. mucronatum }\end{array}$ & $\begin{array}{l}\text { Culture of hairy } \\
\text { root, Culture of } \\
\text { suspension, Seed } \\
\text { extract, root extract, } \\
\text { aerial part, Callus, } \\
\text { Tissue culture, } \\
\text { Aerial Tissue } \\
\text { culture, cell culture }\end{array}$ & $\begin{array}{c}\text { Podophyllotoxin, Podophyllotoxin } \\
\text { derivatives, } \\
\text { 5-methoxypodophyllotoxin, } \\
\text { 6-methylpodophyllotoxin, } \\
\text { 6-methoxypodophyllotoxin }\end{array}$ & {$[86,91,93-107]$} \\
\hline
\end{tabular}

\section{Biosynthesis of Plant Derived Podophyllotoxin}

The understanding of plant pathways is comparatively absolute to the microbial pathways characterized to date. Plant genes that are involved the biosynthetic pathways of various plant-derived clinical drugs remain obscure, hence preventing the transfer of which to heterologous hosts for industrial production. The complete biosynthetic pathway 
(Figure 8) for podophyllotoxin was elucidated only recently in 2015, allowing more facile access to its natural and processed, clinically significant derivatives-otherwise difficult to synthesize on an industrial scale [108].<smiles>NC(Cc1ccccc1)C(=O)O</smiles>

Phenylalanine $\mathrm{H}^{2}$

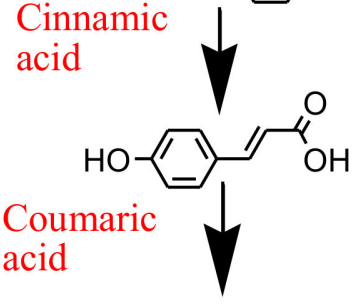

Caffeol

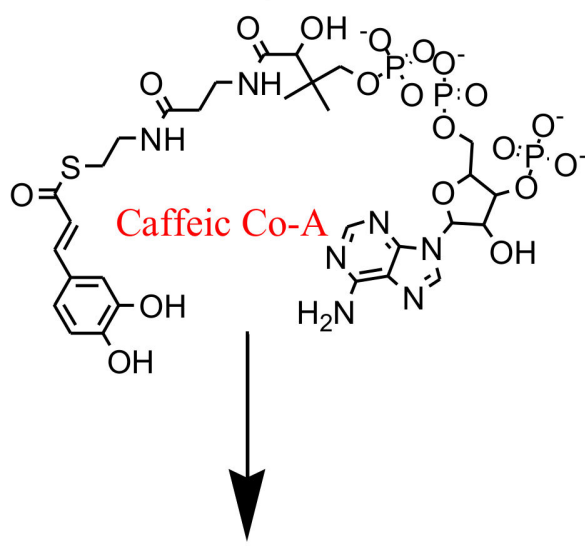<smiles>O=C(O)/C=C/c1ccc(O)c(O)c1</smiles>
acid<smiles>COc1cc(C2COC(c3ccc(O)c(OC)c3)C2)ccc1O</smiles>

Pinoresinol<smiles>[10BH2][13CH3]</smiles><smiles>COc1cc(/C=C/O)cc(OC2OC(CO)C(O)C(O)C2O)c1</smiles>

Coniferyl aldehyde<smiles>CCC(C)CCCCC(=O)C=Cc1ccc(O)c(OC)c1</smiles>

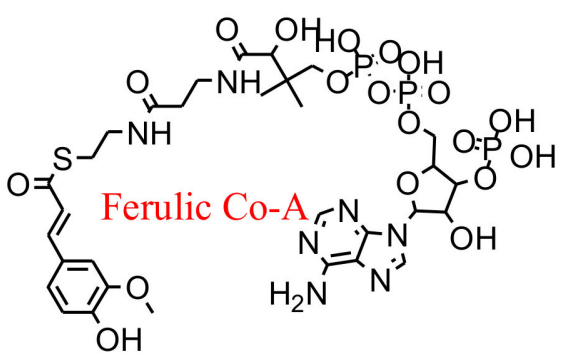

Figure 8. Cont. 


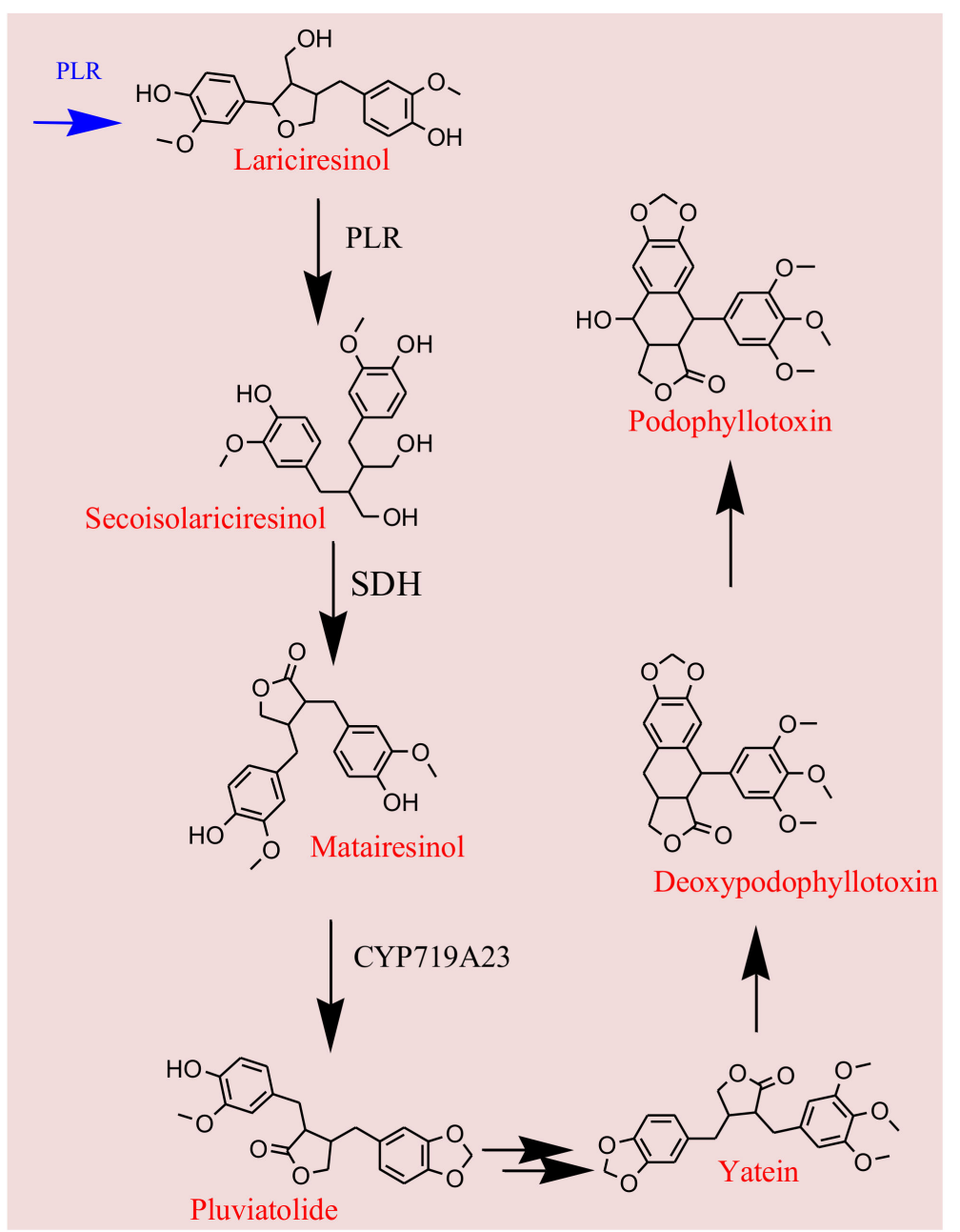

Figure 8. The production of podophyllotoxin in plants takes place in 33 steps where coniferyl alcohol acts as the precursor. The pathway is called phenylpropanoid pathway. In the early steps of podophyllotoxin biosynthesis coniferyl alcohol in formed in nine steps from phenylalanine. Coniferyl alcohol then undergoes a site-selective and unusual enantio-dimerization to form (+)-pinoresinol. Pinoresinol is then reduced to (-)-secoisolariciresinol, which is catalyzed by a dehydrogenase to $(-)$-matairesinol. The next intermediate formed is (-)-pluviatolide, which is methylated to $(-)-5^{\prime}-$ desmethoxy-yatein that is converted to the yatein. Yatein is the intermediate that gets converted to the end product; podophyllotoxin [109].

\section{Microbial Sources of Podophyllotoxin}

Biotechnological procedures for podophyllotoxin production were introduced as a means to overcome its large scale production challenges, which includes the extinction of various podophyllotoxin-plant sources, slow growth of plant sources, exacting constructs and low yields. Micro-organisms, however, demonstrate an enormity of biodiversity, which overdo those of plants. Fungal sources, for instance, have rendered to be a much fruitful alternative to somatic embryogenesis, tissue culturing or macropropagation techniques. The main fungal sources used for industrial podophyllotoxin production are; Trametes hirsuta [110], Fusarium oxysporum [111], Fungus Alternaria [112], Mucor fragilis [113], Fusarium solani [114], Trametes histuria [110], Sebacina vermifera, Phialocephala fortinii [115] and Aspergillus fumigatus [101,116]. The endophytic sources of podophyllotoxin are also tabulated below Table 2 [111] describes the process of podophyllotoxin production from Fusarium oxysporum, which lives on Juniperus recurva. The outcome suggests F. oxysporum to be a promising contender for industrial podophyllotoxin production. In 2009, the specie Juniperus communis L. Horstmann was also found to produce deoxypodophyllotoxin, which 
shared remarkable structural relativity to the lignan of podophyllotoxin [117]. No bacterial sources of podophyllotoxin have yet been identified.

Table 2. Various fungal sources reported as sources of podophyllotoxin.

\begin{tabular}{cccc}
\hline Class & Fungal Endophyte & Host Plant & Ref. \\
\hline Sordariomycetes & $\begin{array}{c}\text { Fusarium oxysporum } \\
\text { Fusarium solani } \\
\text { Fusarium sp. } \\
\text { Pseudallescheria sp. }\end{array}$ & $\begin{array}{c}\text { Juniperus recurva, Podophyllum } \\
\text { hexandrum, Dysosma versipellis, } \\
\text { Sinopodophyllum hexandrum }\end{array}$ & {$[111,114,118,119]$} \\
\hline Agaricomycetes & Trametes hirsuta & Podophyllum peltatum & {$[110]$} \\
\hline Leotiomycetes & Phialocephala fortinii & Podophyllum peltatum & {$[115]$} \\
\hline Dothideomycetes & Alternaria tenuissima & Sinopodophyllum emodi & {$[72]$} \\
\hline Eurotiomycetes & $\begin{array}{c}\text { Aspergillus fumigatus, } \\
\text { Penicillium implicatum }\end{array}$ & $\begin{array}{c}\text { Juniperous communis, Dysoma } \\
\text { veitchii, Diphylleia sinensis }\end{array}$ & {$[117,120,121]$} \\
\hline Ascomycetes & Monilia sp. & Dysoma veitchi & {$[122]$} \\
\hline Zygomycetes & Mucor fragilis & Sinopodophyllum hexandrum & {$[113]$} \\
\hline
\end{tabular}

\section{Parametric Analysis of Podophyllotoxin Biosynthesis}

Studies report five major parameters, which influence the biosynthesis of podophyllotoxin; these include luminosity, chilling units/hours, macro- and micro-nutrients and soil's $\mathrm{pH}$ and nutrient availability. Any fluctuation in the strength of which can result in altered podophyllotoxin yields. In the presence of red-light, for instance, increased the overall product formation in comparison to light of other wavelengths [123]; likewise, chilling units set at $4{ }^{\circ} \mathrm{C}$ were reported to have caused a 5 -folds increase in product yield. The variation in concentrations of macro- and micro-nutrients such as glucose, nitrogen, $\mathrm{NO}_{3}{ }^{-}, \mathrm{PO}_{4}{ }^{3-}$, $\mathrm{Na}^{+}, \mathrm{Fe}^{2+}, \mathrm{Mn}^{2+}$, etc., has shown similar correlation with podophyllotoxin production. Moreover, the acidity or alkalinity levels of the soil in cases for podophyllotoxin producing plants also demonstrate yield modifications. These parameters are tabulated and discussed below Table 3.

Table 3. The influence of varying parameters on yield of plant-biosynthesized podophyllotoxin.

\begin{tabular}{|c|c|c|c|c|}
\hline Parameters & General Effect & Sub-Parameter & Podophyllotoxin Yield & Ref. \\
\hline \multirow{3}{*}{ Light } & \multirow{3}{*}{$\begin{array}{l}\text { Light can increase or decrease the } \\
\text { biosynthesis of podophyllotoxin }\end{array}$} & Red light & Substantial increase & \multirow{3}{*}{ [123] } \\
\hline & & Blue light & Slight increase & \\
\hline & & White light & Decrease & \\
\hline \multirow{2}{*}{$\begin{array}{l}\text { Chilling } \\
\text { Temperature }\end{array}$} & \multirow{2}{*}{$\begin{array}{l}\text { Chilling temperature can increase or } \\
\text { decrease the biosynthesis of } \\
\text { podophyllotoxin }\end{array}$} & $4^{\circ} \mathrm{C}$ & 5 -folds increase & \multirow{2}{*}{ [124] } \\
\hline & & $10{ }^{\circ} \mathrm{C}$ & 3.33-folds increase & \\
\hline \multirow{3}{*}{$\begin{array}{l}\text { Macro } \\
\text { Nutrients }\end{array}$} & \multirow{3}{*}{$\begin{array}{l}\text { At different concentrations major } \\
\text { nutrients can increase or decrease the } \\
\text { biosynthesis of podophyllotoxin }\end{array}$} & Glucose concentration & Highest levels of yield at $60 \mathrm{~g} / \mathrm{L}$ & \multirow{3}{*}{ [125] } \\
\hline & & Phosphate concentration & Highest levels of yield at $1.25 \mathrm{mM}$ & \\
\hline & & Nitrogen concentration & Highest levels of yield at $60 \mathrm{mM}$ & \\
\hline \multirow{3}{*}{$\begin{array}{l}\text { Micro } \\
\text { Nutrients }\end{array}$} & \multirow{3}{*}{$\begin{array}{l}\text { Different ions can influence the yield } \\
\text { of podophyllotoxin }\end{array}$} & $\mathrm{NO}_{3}{ }^{-}, \mathrm{PO}_{4}{ }^{3-}, \mathrm{Na}^{+}, \mathrm{Fe}^{2+}, \mathrm{Mn}^{2+}$ & Positive correlation & \multirow{3}{*}{ [126] } \\
\hline & & $\mathrm{SO}_{4}{ }^{2-}, \mathrm{K}^{+}$ & Negative correlation & \\
\hline & & $\mathrm{Mg}^{2+}, \mathrm{Ca}^{2+}, \mathrm{Cu}, \mathrm{Zn}$ & No correlation & \\
\hline \multirow{3}{*}{ Soil Nutrients } & \multirow{3}{*}{$\begin{array}{l}\text { Podophyllotoxin production can be } \\
\text { increased or decreased by acidic or basic } \\
\text { pH and nutrient availability }\end{array}$} & $\mathrm{pH}$ & $\begin{array}{l}\text { Podophyllotoxin content was increased } \\
\text { significantly (more than } 6.62 \% \text { ) when } \\
\text { pH of soil was } 4.82\end{array}$ & \multirow{3}{*}{ [127] } \\
\hline & & Nitrogen & $\begin{array}{l}\text { Podophyllotoxin content was increased } \\
\text { significantly when nitrogen content } \\
\text { was } 2.7 \%\end{array}$ & \\
\hline & & Carbon & $\begin{array}{l}\text { Podophyllotoxin content was increased } \\
\text { significantly when soil organic carbon } \\
\text { content was } 3.32 \%\end{array}$ & \\
\hline
\end{tabular}




\section{Pharmacological Significance of Podophyllotoxin and Its Derivatives}

Podophyllotoxin and its derivatives possess a wide-spectrum of pharmacological potential. The achievability of broad chemical modifications brings the podophyllotoxin pharmacophore its diverse applicability as a medicinal compound-tabulated in Table 4. Antineoplastic activity is the most outstanding of all its clinical properties. Various studies validate podophyllotoxin derivatives including etopophos, teniposide, etoposide, etoposide phosphate, GL331, NK-611, TOP53 and NPF as anticancer drugs [64,128-132]. Many clinical studies have reported the efficacy of these compounds against various forms of cancer including lung cancer, Wilmstumours, diverse types of genital tumors such as carcinoma verrucosus and for non-Hodgkin lymphoma, multiform glioblastoma lymphoma and nonlymphocytic leukemia [17]. Podophyllotoxin has also shown activity against various (multi) drug resistant tumor cells. As an example, $\mathrm{Hu}$ and coworkers presented a 4 - $\beta$-anilino-podophyllotoxin derivative as a potential anticancer drug against the KB/VCR cells in both conditions; in vivo and in vitro [133]. For the development of new anticancer drugs, podophyllotoxin containing analogues are of prime focus in recent studies. Ming et al. [134] explained that an endophytic fungus named as Dysosma versipellis has both anticancer and antimicrobial properties. The aqueous extract of Podophyllum peltatum [41] fractionated by reverse-phase chromatography was observingly the most active component that was found to cause the inhibition in the replication process of herpes simplex type 1 virus and measles.

Moreover, picropodophyllotoxin, deoxypodophyllotoxin and peltatins are also determined as useful antiviral compounds [135-137]. Activity against Sindbis and cytomegalovirus has also been recorded [138]. They either decrease the capacity of the infected cell to release virus or restrain these viruses in the replication cycle at an essential early stage, following the virus absorption into cells. Not only this, podophyllotoxin can also be used for treating Condyloma acuminatum that is usually caused by HPV (papilloma virus) [139] and for treating other perianal and venereal warts [140]. With a goal to achieve better therapeutic effectiveness, cocktail therapies are currently in use with other registered chemotherapeutic agents, combined with additional techniques that are beneficial in fighting against cancer and other viral infections. Podophyllotoxins with interferon therapy has shown greater effectivity against genital human infections, combination with cisplatin, on the other hand, is useful for treating neuroblastomas. Recently a study reports the study progression of etoposide in phase II clinical trials (ClinicalTrials NTC04356690) as a redeveloped drug to treat COVID-19 patients suffering with cytokine storm complication [141]. Similarly, in recent years podophyllotoxin derivatives have shown some interesting insecticidal activities against the larvae of Brontispa longissima and Mythimna separata [142]. Furthermore, derivatives are also being synthesized and used for the treatment of malaria and psoriasis [143]. Podophyllotoxins also hold dermatological significance and prove to be potential therapeutic agents for psoriasis vulgaris. Podophyllotoxin exhibited considerable ichthyotoxic activity and phyto growth inhibitory activities, even though the effects were weaker as compared to deoxy podophyllotoxin, in all cases observed [144,145].

Besides the major antiviral and anticancer activities, podophyllotoxin and its derived compounds have also exhibited some further interesting activities such as antitrypanosomal activity, antimelanocortin-4 receptor (MC4R) activity, antioxidative activity, immunosuppressive, antioxidative, antispasmogenic, hypolipidemic, emetic, laxative and anti-inflammatory activity. Moreover, during the last century, many trials were carried out in an attempt to cure diseases such as syphilis, cough, gonorrhea, dropsy, gout, psoriasis, tuberculosis, tumor, menstrual disorders and venereal warts by using podophyllotoxins. According to Hartwell et al. (1951), podophyllotoxin is particularly abundant in the genus Podophyllum that has been utilized since ancient times as bothanthelminthic and cathartic agents, for medicinal purposes [3]. Podophyllotoxin is demonstrated as a promising and relatively safe drug, for treating genital warts and is also an active ingredient of registered wartec ointments and condylox liquids. 
Table 4. Pharmacological activities of podophyllotoxin and its derivatives.

\begin{tabular}{|c|c|c|c|c|}
\hline Activity & $\begin{array}{l}\text { Podophyllotoxin } \\
\text { Derivative }\end{array}$ & Mechanism & Conclusion & Ref. \\
\hline Cytotoxic activity & Cleistantoxin & $\begin{array}{l}\text { Activity was checked } \\
\text { against MCF-7, } \\
\text { MCF-7R, KBand HT29 } \\
\text { cancer cell lines }\end{array}$ & $\begin{array}{l}\text { Cleistantoxin showed strong cytotoxic } \\
\text { activity }\end{array}$ & [146] \\
\hline Antibacterial activity & $\begin{array}{l}\text { New precursors of } \\
\text { podophyllotoxin were } \\
\text { synthesized, and } \\
\text { screened to check their } \\
\text { antibacterial activity }\end{array}$ & $\begin{array}{l}\text { Activity was checked } \\
\text { against Klebsiella } \\
\text { pneumoniae, } \\
\text { Streptococcus faecalis, } \\
\text { Citrobacter sp., } \\
\text { Pseudomonas aeruginosa, } \\
\text { Escherchia coli, } \\
\text { Salmonella typhi and } \\
\text { Shigella sonnei }\end{array}$ & $\begin{array}{c}\text { Ethyl-2-(3'-methyl-4'- } \\
\text { methoxybenzoyl)-3-(4" } \\
\text { methoxyphenol)-cyclopropane-1- } \\
\text { carboxylic acid and } \\
\text { Ethyl-2-(3'-methyl-4'- } \\
\text { methoxybenzyol-3-1 } 3^{\prime \prime}, \\
4^{\prime \prime} \text {-dimethoxyphenyl)-cyclopropane- } \\
\text { carboxylic acid, both of them showed } \\
\text { significant antibacterial activity }\end{array}$ & [147] \\
\hline Antitumour activity & $\begin{array}{l}\text { VP } 16-213 \\
(\mathrm{NSC}-141540)\end{array}$ & $\begin{array}{l}\text { Activity was checked } \\
\text { against L1210 ascites } \\
\text { tumour in N/D mice }\end{array}$ & $\begin{array}{l}\text { In } 24 \text { hours, divided treatment after } \\
\text { every } 3 \text { hours, resulted in significant } \\
\text { cure, hence, VP 16-213 is a cell cycle } \\
\text { specific drug }\end{array}$ & [148] \\
\hline Insecticidal activity & $\begin{array}{l}20 \text { podophyllotoxin } \\
\text { analogues were tested }\end{array}$ & $\begin{array}{l}\text { Activity was checked } \\
\text { against fifth-instar } \\
\text { larvae of Brontispa } \\
\text { longissima in vivo }\end{array}$ & $\begin{array}{l}\text { Among } 20 \text { analogues } \\
\text { Deoxypodophyllotoxin showed more } \\
\text { protential for insecticidal activity than } \\
\text { a commercial insecticide } \\
\text { (toosendanin) }\end{array}$ & [149] \\
\hline \multirow{2}{*}{ Antineoplastic activity } & $\begin{array}{l}\text { New hybrids of } \\
\text { podophyllotoxin and } \\
\text { indirubin }\end{array}$ & $\begin{array}{l}\text { Activity was checked } \\
\text { against human } \\
\text { leukemia cancer cells as } \\
\text { a multifunctional } \\
\text { anti-MDR agent }\end{array}$ & $\begin{array}{l}\text { Podophyllotoxin-indirubin hybrid } \\
\text { (Da-1) showed potential to overcome } \\
\text { drug resistance. It is a novel hybrid } \\
\text { havingpotent antiproliferative activity }\end{array}$ & [150] \\
\hline & $\begin{array}{l}\text { Cyclolignans, derived } \\
\text { from podophyllotoxin }\end{array}$ & $\begin{array}{l}\text { Activity was checked } \\
\text { againstA-549 human } \\
\text { lung carcinoma, P-388 } \\
\text { murine leukemia and } \\
\text { HT-29 colon carcinoma }\end{array}$ & $\begin{array}{l}\text { A number of substances were active in } \\
\text { assay at concentrations below } 1 \mathrm{pM} ; \\
\text { deoxypodophyllotoxin being the most } \\
\text { potent compound in all cases }\end{array}$ & [151] \\
\hline
\end{tabular}

\section{Patents}

In the past decade, numerous attempts have been globally to produce derivatives or compositions of podophyllotoxins in order to overcome their natural dose-limiting toxicity, poor biodistribution and low aqueous solubility. These inventions have found extensive application for effective chemotherapeutic purposes. These inventions have succeeded at demonstrating sufficient activity and can considerably contribute to future studies, some of these new derivatives are tabulated below (Table 5). 
Table 5. Novel patented podophyllotoxin derivatives.

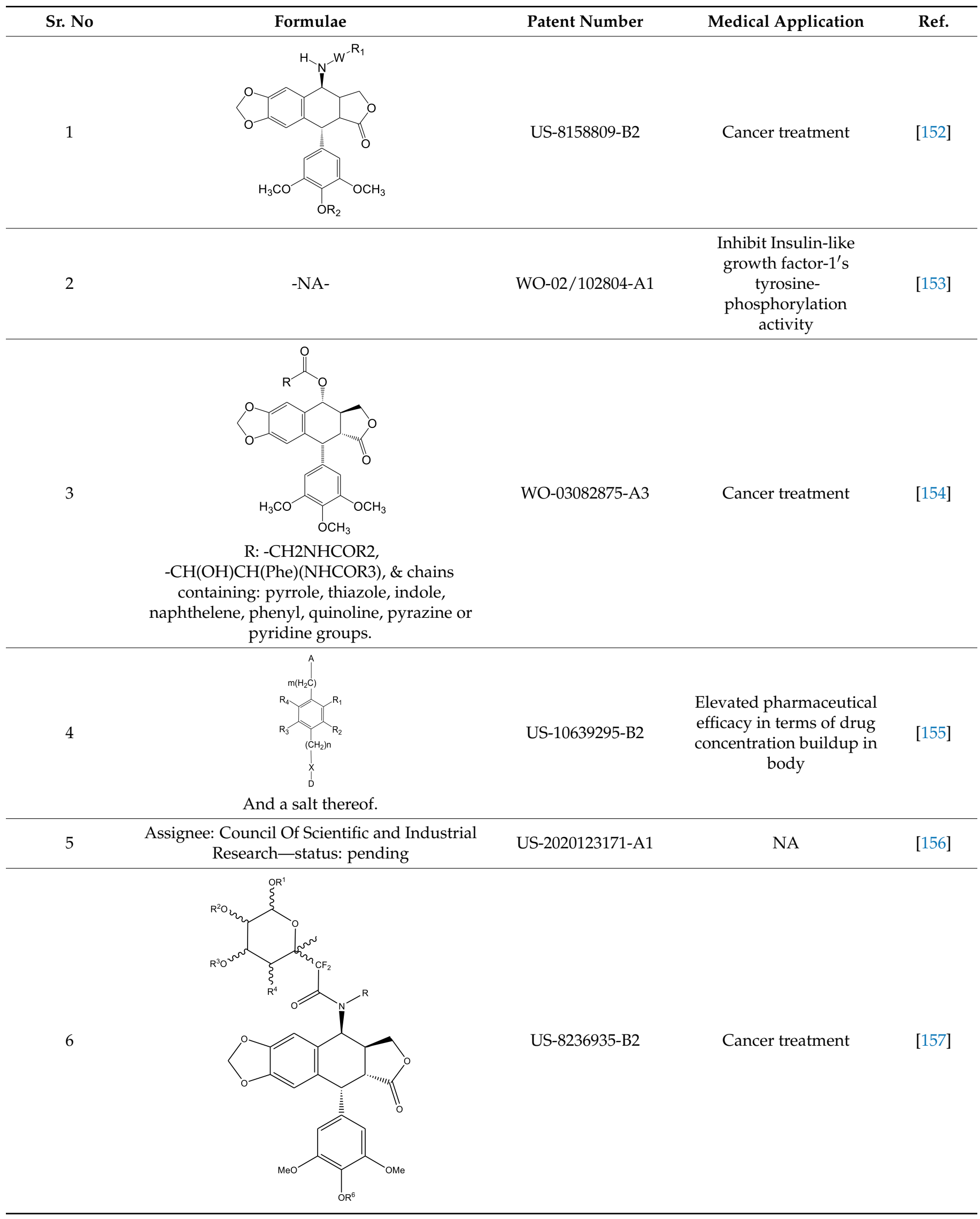


Table 5. Cont.

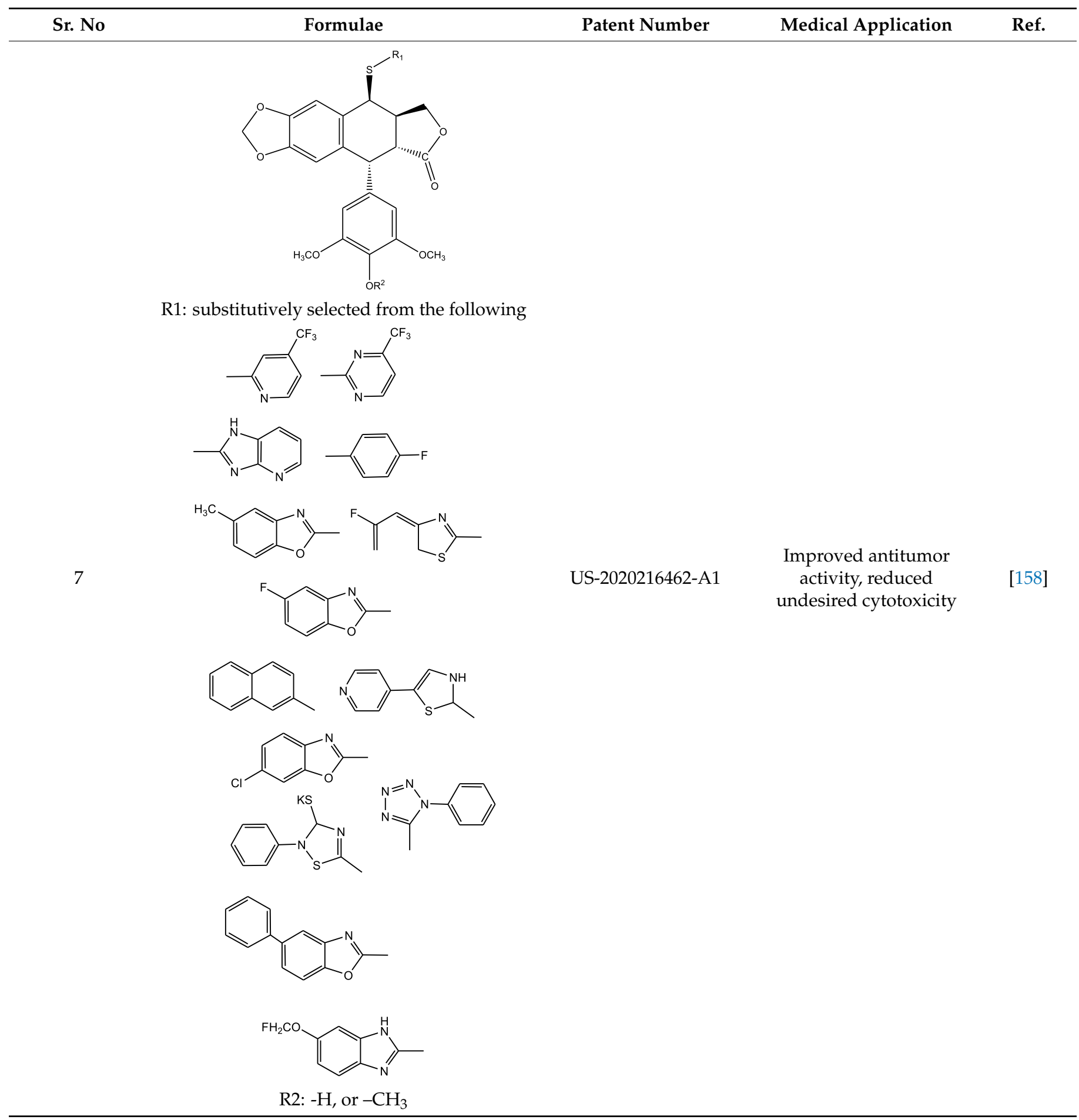


Table 5. Cont.

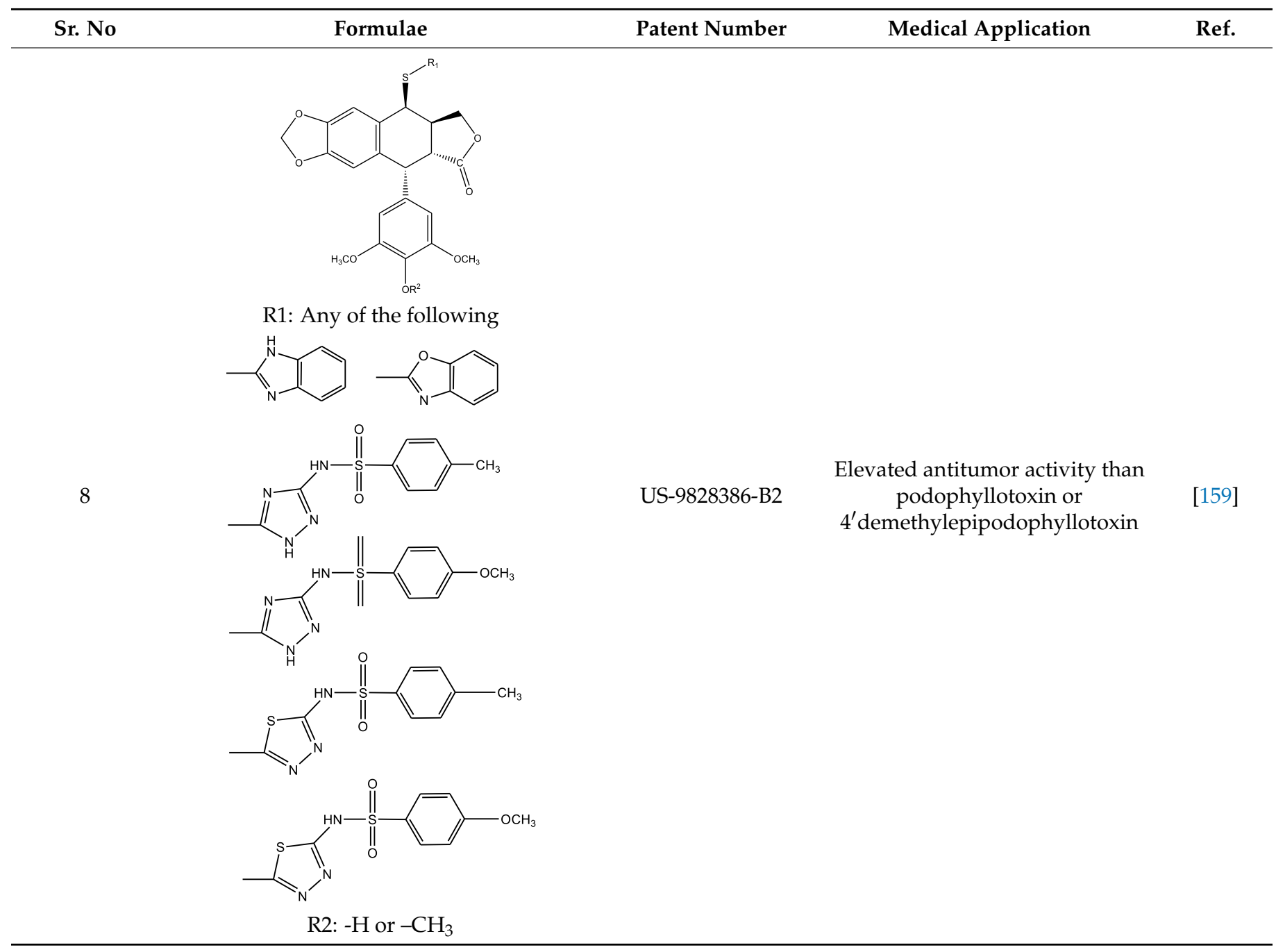

The great interest of institutional researchers and pharmaceutical companies is also validated by a surge in number of patents protecting various inventions involving podophyllotoxin. Searching the term "podophyllotoxin" gave 93,446 results in the Google patent database while 26,582 in the Patent Lens database with the first patent application filed in 1967-12-06 and granted in 1970-08-18. When "podophyllotoxin" is used as keywords for the the patents and/or patent applications annual filed (Figure 9), key applicant companies (Figure 10), key inventors (Figure 11), and key owners based in US (Figure 12) [160,161] 


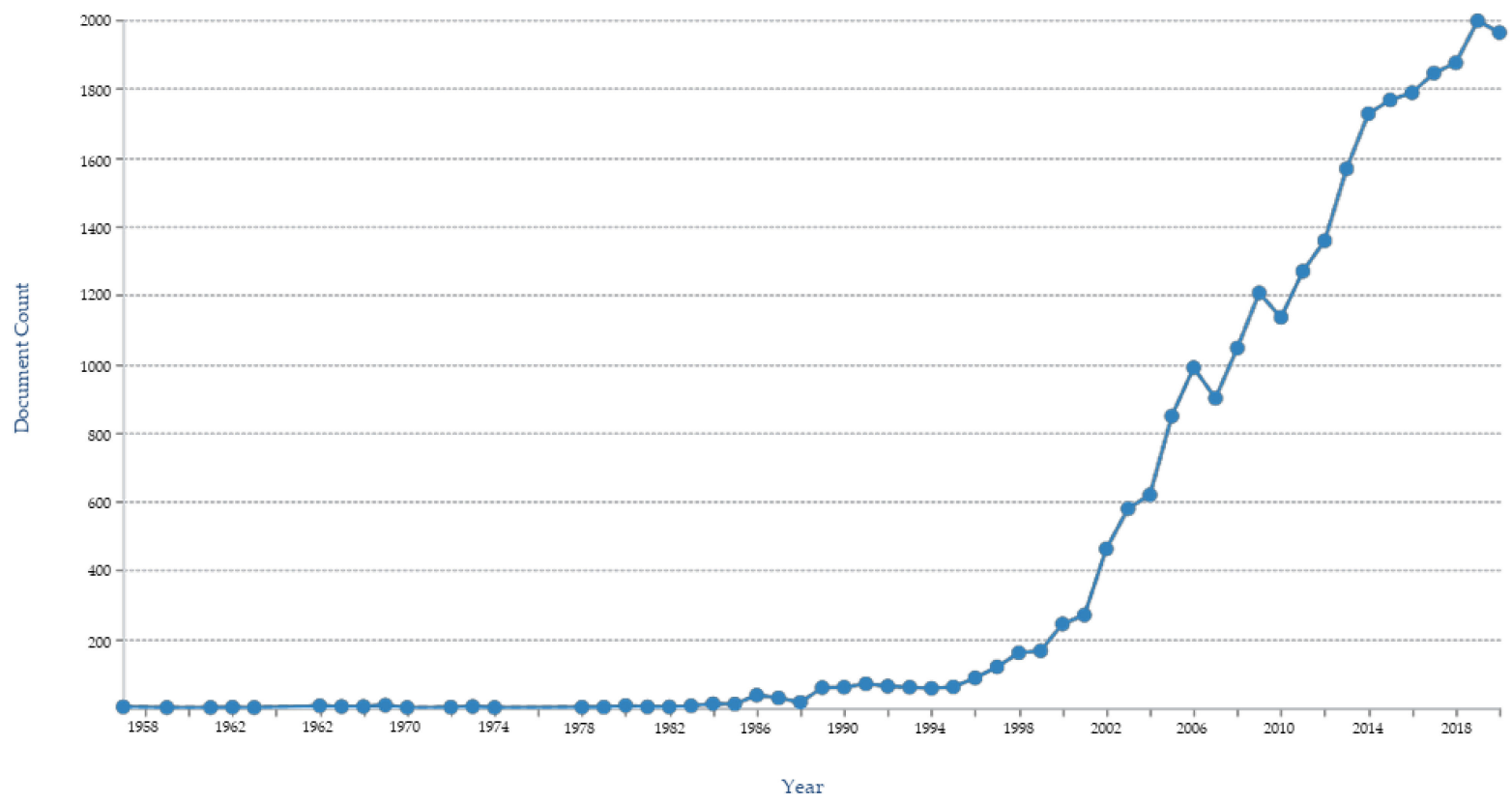

Figure 9. Year wise patent publications filed on podophyllotoxin.

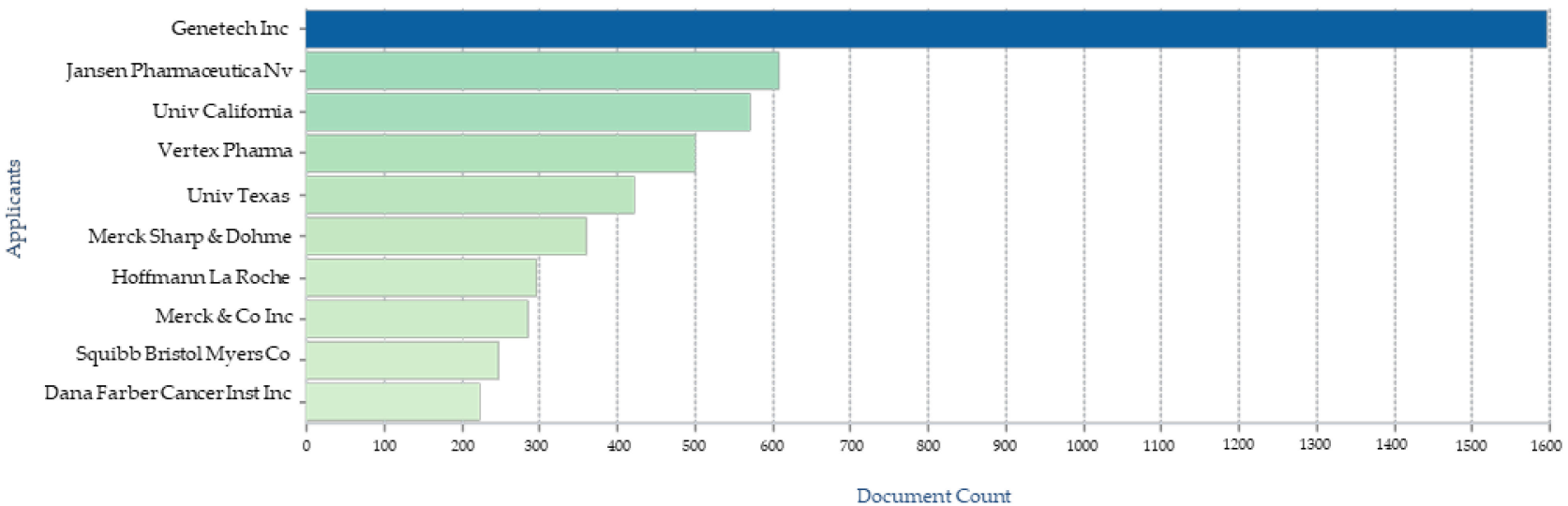

Figure 10. Key patent filing companies on podophyllotoxin.

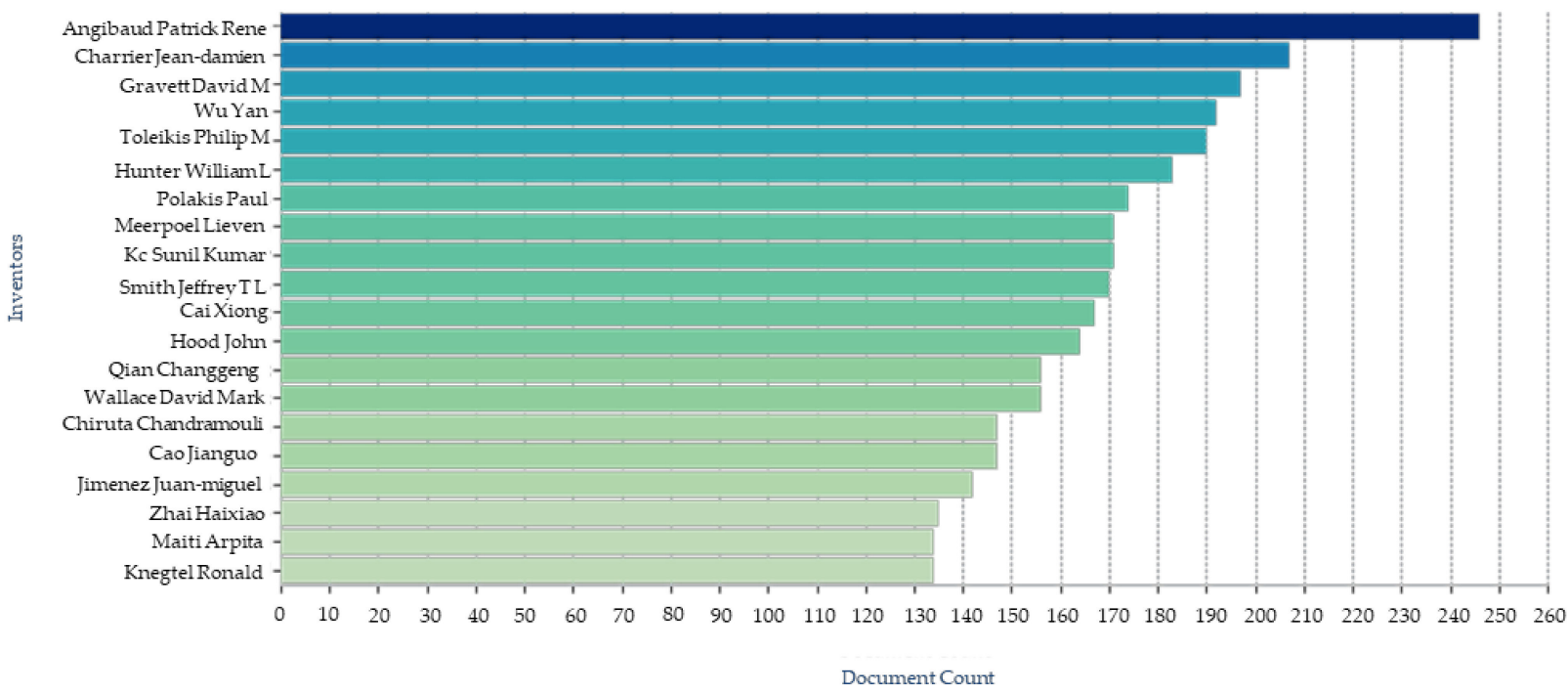

Figure 11. Key inventors in the podophyllotoxin field. 


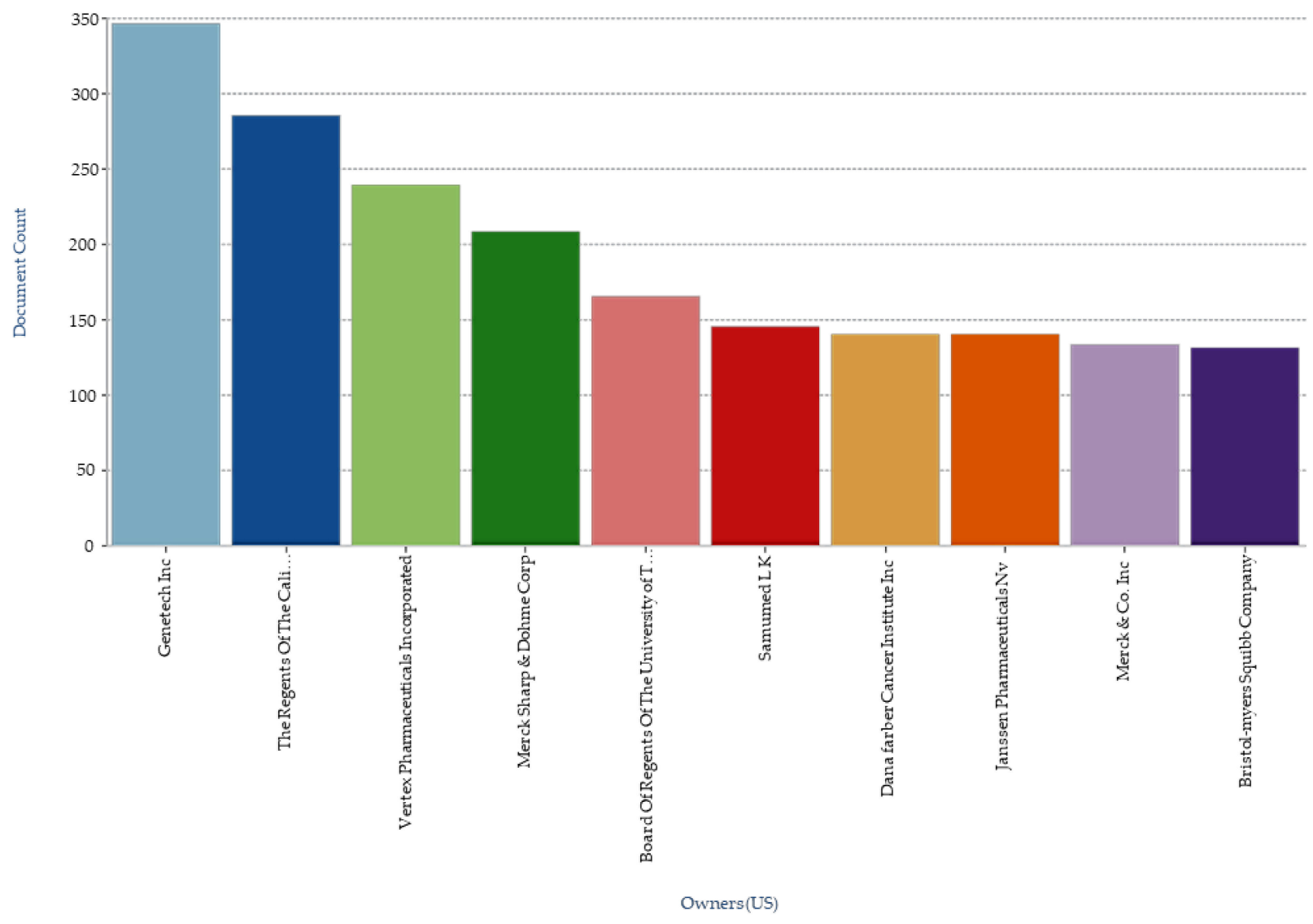

Figure 12. Top US owners of patents related to podophyllotoxin.

\section{Conclusions}

Novel approaches towards structure optimization and the finding of alternative sources can help unravel less toxic, more efficient and easy to yield podophyllotoxin and its derivatives. Being known for decades as the main bioactive compound in various traditional medicinal formulas, these compounds were later approved for clinical use against a number of health conditions. In the recent pandemic, various known drugs were repurposed against the novel coronavirus strain 2019. Amongst this struggle of trial and error, etoposide-a podophyllotoxin derivative well cited for its antineoplastic activityhas also been redeveloped to manage cytokine storm complication in COVID-19 patients. This finding opens new potential for podophyllotoxin, its derivatives and its congeners to be explored. For as the growing demand for podophyllotoxin is increasing, plant sources are proving to be an unreliable option for the future, this explains the exigency of utilizing microbial biotransformation as a considerable approach along with the need of devoted effort towards rationally designing the new generation of the group of podophyllotoxinderived compounds.

Author Contributions: All authors have made a substantial contribution to the review. U.F.G., S.I.T., R.M. and H.M. conceptualized the topic and the manuscript structure, Z.S., M.M., B.P. and I.J. contributes to the drafting, writing and preparation of the original and final draft. U.F.G., A.M., H.M. and M.Z.-U.-H. critically supervised and revised the final version thereof. All authors have read and agreed to the published version of the manuscript.

Funding: This research received no external funding.

Institutional Review Board Statement: Not applicable.

Informed Consent Statement: Not applicable. 
Data Availability Statement: All the data produced here is available and can produced when required.

Conflicts of Interest: The authors declare no conflict of interest.

\section{References}

1. Cane, C.; Moracs, R.M. Podophyllotoxin. Phytochemistry 2000, 54, 115-120. [CrossRef]

2. Gordaliza, M.; Garcia, P.A.; Miguel del Corral, J.M. Podophyllotoxin: Distribution, sources, applications, and new cytotoxic derivatives. Toxicon 2004, 44, 441-459. [CrossRef] [PubMed]

3. Hartwell, J.L.; Schrecker, A.W. Components of Podophyllin. V. The Constitution of Podophyllotoxin. J. Am. Chem. Soc. 1951, 73, 2909-2916. [CrossRef]

4. Ayres, D.C.; Loike, J.D. Lignans, Chemical, Biological and Clinical Properties; Cambridge University Press: Cambridge, UK, 1990; Chapters 3 and 4 .

5. King, J. Discovery of Podophyllin. Coll. J. M. Sci. 1875, 2, 557-559.

6. Liu, C.J.; Hou, S.S. Current Research Status of Podophyllotoxin Lignans. Nat. Prod. Res. Dev. 1997, 9, 81-89.

7. Chen, Y.H. A Study of the Resources of Chinese Podophyllin Plants. Acta Pharm. Sin. 1979, 14, 101-107.

8. Yang, X.Z.; Shao, H.; Zhang, L.Q.; Zhou, C.; Xuan, Q.; Yang, C.Y. Present Situation of Studies on Resources of Podophyllotoxin. Chin. Tradit. Herb. Drugs 2001, 32, 1042-1044.

9. Liu, H.J.; Xu, Y.; Su, G.Q.; Li, C.Y.; Wang, L.; Liu, Y.J. Research Progress in Sinopodophyllum emodi. Chin. Tradit. Herb. Drugs 2004, 35, 98-100.

10. Macrae, D.W.; Towers, N.G.H. Biological Activity of Lignans. Phytochemistry 1984, 23, 1207-1220. [CrossRef]

11. Bohlin, L.; Rosen, B. Podophyllotoxin derivatives: Drug discovery and development. Drug Discov. Today 1996, 1, 343-351. [CrossRef]

12. Cragg, G.M.; Kingston, D.G. Anticancer Agents from Natural Products, 2nd ed.; CRC Press: Boca Raton, FL, USA, $2011 ;$ p. 97.

13. Podwyssotzki, V. The active constituents of podophyllotoxin. Pharm. J. Trans. 1881, 12, 217-218.

14. Podwyssotzki, V. On the active constituents of podophyllin. Am. J. Pharm. 1882, 12, 102-115.

15. Podwyssotzki, V. Pharmakologische Studien uber podophyllum peltatum. NaunynSchmied Arch. Exp. Path. Phar. 1884, 13, 29-52. [CrossRef]

16. Species Plantrum; Salvius: Stockholm, Sweden, 1753; p. 505.

17. Yu, X.; Che, Z.P.; Xu, H. Recent Advances in the Chemistry and Biology of Podophyllotoxins. Chem. Eur. J. 2016, 10, 1002-1006. [CrossRef]

18. Stoll, A.; Renz, J.; Wartburg, A.V. The isolation of podophyllotoxin glucoside. J. Am. Chem. Soc. 1954, 76, 3103-3104. [CrossRef]

19. Stoll, A.; von Wartburg, A.; Angliker, E.; Renz, J. The isolation of 4'- Demethylpodophyllotoxin glucoside from rhizomes podophyllum emodi wall. J. Am. Chem. Soc. 1954, 76, 5004-5005. [CrossRef]

20. Emmenggger, H.; Stahelin, H.; Rutschmann, J.; von Wartburg, A. Chemistry and Pharmacology of podophyllum glucosides and derivatives. I. Arzneim. 1961, 11, 327-333.

21. Kuhn, M.; von Wartburg, A. Mitosis-inhibiting substances. XXI. Synthesis of epipodophyllotoxin b-D-glucopyranoside. Helv. Chim. Acta 1968, 51, 1631-1641. [CrossRef] [PubMed]

22. Kuhn, M.; von Wartburg, A. Mitosis-inhibiting substances. glycosidation process.II. Glycosides of 4"-demethylepipodophyllotoxin. Helv. Chim. Acta 1969, 52, 948-955. [CrossRef] [PubMed]

23. Keller-Juslen, C.; Kuhn, M.; Von Wartburg, A.; Staehelin, H. Synthesis and antimitotic activity of glycosidic lignan derivatives related to podophyllotoxin. J. Med. Chem. 1971, 14, 936-940. [CrossRef] [PubMed]

24. Joel, S. The clinical pharmacology of etoposide. An update. Cancer Treat. Rev. 1996, 22, 179-221. [CrossRef]

25. Stahelin, H.F.; von Wartburg, A. The Chemical and Biological Route from Podophyllotoxin Glucoside to Etoposide: Ninth Cain Memorial Award Lecture. Cancer Res. 1991, 51, 5-15.

26. Ardalani, H.; Avan, A.; Ghayour-Mobarhan, M. Podophyllotoxin: A novel potential natural anticancer agent. Avicenna J. Phytomed. 2017, 7, 285-294.

27. Mross, K.; Huttmann, A.; Herbst, K.; Hanauske, A.R.; Schilling, T.; Manegold, C.; Burk, K.; Hossfeld, D.K. Pharmacokinetics and pharmacodynamics of the new podophyllotoxin derivative NK 611 A study by the AIO groups PHASE-I and APOH. Cancer Chemother. Pharmacol. 1996, 38, 217-224. [CrossRef] [PubMed]

28. Huang, T.S.; Lee, C.C.; Chao, Y.; Shu, C.H.; Chen, L.T.; Chen, L.L.; Chen, M.H.; Yuan, C.C.; Whang-Peng, J. A novel podophyllotoxin-derived compound GL331 is more potent than its congener VP-16 in killing refractory cancer cells. Pharm. Res. 1999, 16, 997-1002. [CrossRef]

29. Lee, C.C.; Huang, T.S. A novel topoisomerase GL331 preferentially induces DNA cleavage at (C/G)T sites and can cause telomere DNA damage. Pharm. Res. 2001, 18, 846-851. [CrossRef] [PubMed]

30. Solary, E.; Leteurtre, F.; Paull, K.D.; Scudiero, D.; Hamel, E.; Pommier, Y. Dual inhibition of topoisomerase II and tubulin polymerization by azatoxin, a novel cytotoxic agent. Biochem. Pharm. 1993, 45, 2449-2456. [CrossRef]

31. Arora, R. Medicinal Plant Biotechnology; CAB International: Wallingford, UK, 2010.

32. You, Y. Podophyllotoxin derivatives: Current synthetic approaches for new anticancer agents. J. Curr. Pharm. Des. 2005, 11, 1695-1717. [CrossRef] [PubMed] 
33. Bromberg, L. Polyether-modified poly (acrylic acid): Synthesis and applications. Ind. Eng. Chem. Res. 1998, 37, 4267-4274. [CrossRef]

34. Von-Schreier, E. Partial synthese der 6, 7-Dimethoxy-Analogen von Podophyllotoxin, Epi-, Neo-, und Desoxy-podophyllotoxin. Helv. Chim. Acta 1964, 47, 1529-1554. [CrossRef]

35. Wang, Z.Q.; Hu, H.; Chen, H.X.; Cheng, Y.C.; Lee, K.H. New 4 beta-substituted aniline derivatives of 6,7-O,O-demethylene-4'-Odemethylpodophyllotoxin and related compounds as potent inhibitors of human DNA topoisomerase II. J. Med. Chem. 1992, 35, 871-877. [CrossRef] [PubMed]

36. Cho, S.J.; Kashiwada, Y.; Bastow, K.F.; Cheng, Y.C.; Lee, K.H. Podophenazine, 2",3"'-Dichloropo-dophenazine, Benzopodophenazine, and Their $4 \mathrm{~b}-\mathrm{p}$-Nitroaniline Derivatives as Novel DNA Topoisomerase II Inhibitors. J. Med. Chem. 1996, 39, 1396-1402. [CrossRef]

37. Cho, S.J.; Tropsha, A.; Suffness, M.; Cheng, Y.C.; Lee, K.H. Three-Dimensional Quantitative Structure-Activity Relationship Study of 4'-O-Demethyl-epipodophyllotoxin Analogs Using the Modified CoMFA/q2 -GRS Approach. J. Med. Chem. 1996, 39, 1383-1395. [CrossRef]

38. Hartwell, J.L. $\alpha$-Peltatin, a new compound isolated from podophyllum peltatum. J. Am. Chem. Soc. 1947, 69, 2918. [CrossRef] [PubMed]

39. Stoll, A.; von Wartburg, A.; Renz, J. The isolation of a-peltatin glucoside from the rhizomes of Podophyllum peltatum L. J. Am. Chem. Soc. 1955, 77, 1710-1711. [CrossRef]

40. Nagar, N.; Jat, R.K.; Saharan, R.; Verma, S.; Sharma, D.; Bansal, K. Podophyllotoxin and their Glycosidic derivatives. Pharmacophore 2011, 2, 87-97.

41. Bedows, E.; Hatfield, G.M. An Investigation of the Antiviral Activity of Podophyllum peltatum. J. Nat. Prod. 1982, 45, 725-729. [CrossRef]

42. Thurston, L.S.; Irie, H.; Tani, S.; Han, F.S.; Liu, Z.C.; Cheng, Y.C.; Lee, K.H. Inhibition of human DNA topoisomerase II by podophyllotoxin and alpha-peltatin analogs. J. Med. Chem. 1986, 29, 1547-1550. [CrossRef]

43. Thurston, L.S.; Imakura, Y.; Haruna, M.; Li, D.H.; Liu, Z.C.; Liu, S.Y.; Cheng, Y.C.; Lee, K.H. Inhibition of human DNA topoisomerase II by cytotoxic ether and ester derivatives of podophyllotoxin and alpha-peltatin. J. Med. Chem. 1989, 32, 604-608. [CrossRef] [PubMed]

44. Beers, S.A.; Imakura, Y.; Dai, H.J.; Li, D.H.; Cheng, Y.C.; Lee, K.H. Synthetic Ring C Aromatized Podophyllotoxin Analogues as Potential Inhibitors of Human DNA Topoisomerase II. J. Nat. Prod. 1988, 51, 901-905. [CrossRef]

45. Canjanamurthy, K.; Lokanatharai, M. Synthesis of Podophyllotoxin \& related analogues: Part II-Synthesis of B-apopicrophyllin analogues with modified Hydroaromatic ring-B. Indian J. Chem. 1985, 24, 505-508.

46. Canjanamurthy, K.; Lokanatharai, M. Synthesis of Podophyllotoxin \& related analogues: Part III-Synthesis of ß-apopicrophyllin analogues with modified lactone ring. Indian J. Chem. 1987, 26, 131-135.

47. He, Y.; Ma, W.Y.; Zhang, C.N. The effects of unsaturated factors on ring C to chemical Properties of podophyllotoxin analogues J. Chin. Pharm. Sci. 2001, 10, 81-84.

48. Kamal, A.; Reddy, S.T.; Polepalli, S.; Shalini, N.; Reddy, V.G.; Subba Rao, A.V.; Shankaraiah, N. Synthesis and biological evaluation of podophyllotoxin congeners as tubulin polymerization inhibitors. Bioorg. Med. Chem. 2014, 22, 5466-5475. [CrossRef]

49. Guo, H.Z.; Guo, D.A.; Fei, X.Y.; Cui, Y.J.; Zheng, J.H. Biotransformation of podophyllotoxin to picropodophyllin by microbes. J. Asian Nat. Prod. Res. 1998, 1, 99-102. [CrossRef]

50. Larsson, M.A. Cyclolignans as inhibitors of the insulin-like growth factor-I receptor. Cancer Res. 2007, 67, 2899. [CrossRef]

51. Vasilcanu, R.; Vasilcanu, D.; Rosengren, L.; Natalishvili, N.; Sehat, B.; Yin, S.; Girnita, A.; Axelson, M.; Girnita, L.; Larsson, O. Picropodophyllin induces down regulation of the insulin-like growth factor 1 receptor: Potential mechanistic involvement of Mdm2 and beta-arrestin. Oncogene 2008, 27, 1629-1638. [CrossRef]

52. Walter, J.; Gensler, C.D.; Murthy, M.H.T. Non-enolizable podophyllotoxin derivatives. J. Med. Chem. 1977, 20, 635-644.

53. Glinski, M.B.; Freed, J.C.; Durst, T. Preparation of 2-substituted podophyllotoxin derivatives. J. Org. Chem. 1987, 52, 2749-2753. [CrossRef]

54. Van-Vliet, D.S.; Lee, K.H. A high yield preparation of 2-fluoropodophyllotoxin. Tetrahedron. Lett. 1999, 40, 2259-2262. [CrossRef]

55. Van-Vliet, D.S.; Tachibana, Y.; Bastow, K.F.; Huang, E.S.; Lee, K.H. Design, Synthesis, and Biological Testing of 4b-Anilino-2fluoro-4'-demethylpodophyllo-toxin Analogues as Cytotoxic and Antiviral Agents. J. Med. Chem. 2001, 44, 1422-1428. [CrossRef]

56. Laatsch, H.; Ernst, B.P.; Noltemeyer, M. Synthesis of Sterically Fixed Podophyllotoxin. Liebigs Ann. 1996, 1996, 731-737. [CrossRef]

57. Zhou, X.M.; Lee, K.J.H.; Cheng, J.; Wu, S.S.; Chen, H.X.; Guo, X.; Cheng, Y.C.; Lee, K.H. New gamma-lactone ring-modified arylamino etoposide analogs as inhibitors of human DNA topoisomerase II. J. Med. Chem. 1994, 37, 287-292. [CrossRef] [PubMed]

58. Gordaliza, M.; Faircloth, G.T.; Castro, M.A.; Miguel del Corral, J.M.; Lopez-Vazquez, M.L.; Feliciano, S.A. Immunosuppressive cyclolignans. J. Med. Chem. 1996, 39, 2865-2868. [CrossRef]

59. Subrahmanyam, D.; Renuka, B.; Laxmana-Rao, C.V.; Sagar, S.P.; Deevi, D.S.; Babu, J.M.; Vyas, K. Novel D-ring analogues of podophyllotoxin as potent anti-cancer agents. Bioorg. Med. Chem. Lett. 1998, 8, 1391-1396. [CrossRef]

60. Subrahmanyam, D.; Renuka, B.; Sunil, K.G.; Vandana, V.; Deevi, D.S. 9-Deoxopodophyllotoxin derivatives as anti-cancer agents. Bioorg. Med. Chem. Lett. 1999, 9, 2131-2134. [CrossRef] 
61. Gaspar, N.; Occean, B.V.; Pacquement, H.; Bompas, E.; Bouvier, C.; Brisse, H.J.; Castex, M.P.; Cheurfa, N.; Corradini, N.; Delaye, J.; et al. Results of methotrexate-etoposide-ifosfamide based regimen (M-EI) in osteosarcoma patients included in the French OS2006/sarcome-09 study. Eur. J. Cancer 2018, 88, 57-66. [CrossRef] [PubMed]

62. Lau, W.; Sattely, E.S. Six enzymes from mayapple that complete the biosynthetic pathway to the etoposide aglycone. Science 2015, 349, 1224-1228. [CrossRef]

63. Jia, K.Z.; Zhan, X.; Li, H.M.; Shen, Y.; Qi, Q.; Zhang, Y.; Li, Y.Z.; Tang, Y.J. A novel podophyllotoxin derivative with higher anti-tumor activity produced via $4^{\prime}$-demethylepipodophyllotoxin biotransformation by Penicillium purpurogenum. Process Biochem. 2020, 96, 220-227. [CrossRef]

64. Liu, Y.Q.; Yang, L.; Tian, X. Podophyllotoxin: Current Perspectives. Curr. Bioact. Compd. 2007, 3, 37-66.

65. Hernandez, A.P.; Diez, P.; Garcia, P.A.; Perez-Andres, M.; Ortega, P.; Jambriana, P.G.; Diez, D.; Castro, M.A.; Fuentes, M. A Novel Cytotoxic Conjugate Derived from the Natural Product Podophyllotoxin as a Direct-Target Protein Dual Inhibitor. Molecules 2020, 25, 4258. [CrossRef]

66. Kumar, P.; Pal, T.; Sharma, N.; Kumar, V.; Sood, H.; Chauhan, R.S. Expression analysis of biosynthetic pathway genes vis-à-vis podophyllotoxin content in Podophyllum hexandrum Royle. Protoplasma 2015, 252, 1253-1262. [CrossRef]

67. Rollinger, J.M.; Zidorn, C.; Dobner, M.J.; Ellmerer, E.P.; Stuppner, H. Lignans, phenylpropanoids and polyacetylenes from Chaerophyllum aureum L. (Apiaceae). Z. Nat. C 2003, 58, 553-557. [CrossRef] [PubMed]

68. Al-Juaid, S.S.; Abdel-Mogib, M. A novel podophyllotoxin lignan from Justicia heterocarpa. Chem. Pharm. Bull. 2004, 52, 507-509. [CrossRef] [PubMed]

69. Yu, P.Z.; Wang, L.P.; Chen, Z.N. A new podophyllotoxin-type lignan from Dysosma versipellis var. tomentosa. J. Nat. Prod. 1991, 54, 1422-1424. [CrossRef]

70. Bedir, E.; Khan, I.; Moraes, R.M. Bioprospecting for Podophyllotoxin. In Trends in New Crops and New Uses; Janick, J., Whipkey, A., Eds.; ASHS Press: Alexandria, Egypt, 2002; pp. 545-549.

71. Gohar, U.F.; Iqbal, I.; Shah, Z.; Mukhtar, H.; Zia-Ul-Haq, M. COVID-19: Recent Developments in Therapeutic Approaches. In Alternative Medicine Interventions for COVID-19; Zia-Ul-Haq, M., Bin-Jumah, M.N., Alothamn, S.I., Henidi, H.A., Eds.; Springer: Cham, Switzerland, 2021; pp. 249-274.

72. Liang, Z.; Zhang, J.; Xuan, Z.; Li, J.; Xiaoqian, Z.; Zhao, C. Endophytic fungus from Sinopodophyllum emodi (Wall.) ying that produces Podophyllotoxin. J. Chromatogr. Sci. 2016, 54, 175-178. [PubMed]

73. Karuppaiya, P.; Tsay, H.S. Enhanced production of podophyllotoxin, kaempferol, and quercetin from callus culture of Dysosma pleiantha (Hance) woodson: An endangered medicinal plant. Biotech. Appl. Biochem. 2019, 67, 95-104. [CrossRef] [PubMed]

74. Bianchi, E.; Caldwell, M.E.; Cole, J.R. Antitumor agents from Bursera microphylla (Burseraceae) I. Isolation and characterization of deoxypodophyllotoxin. J. Pharm. Sci. 1968, 57, 696-697. [CrossRef] [PubMed]

75. Provan, G.J.; Waterman, P.G. Picropolygamain: A New Lignan from Commiphora incisa Resin1. Planta Med. 1985, 51, 271-272. [CrossRef]

76. Wickramaratne, D.B.M.; Mar, W.; Chai, H.; Castillo, J.J.; Farnsworth, N.R.; Soejarto, D.D.; Cordell, G.A.; Pezzuto, J.M.; Kinghorn, A.D. Cytotoxic constituents of Bursera permollis. Planta Med. 1995, 61, 80-81. [CrossRef] [PubMed]

77. Jutiviboonsuk, A.; Zhang, H.; Tan, G.T.; Ma, C.; Van-Hung, N.; Cuong, N.M.; Bunyapraphatsara, N.; Soejarto, D.D.; Fong, H.H. Bioactive constituents from roots of Bursera tonkinensis. Phytochemistry 2005, 66, 2745-2751. [CrossRef]

78. Velazquez-Jimenez, R.; Torres-Valencia, J.M.; Cerda-García-Rojas, C.M.; Hernandez-Hernández, J.D.; Roman-Marín, L.U.; Manríquez-Torres, J.J.; Gomez-Hurtado, M.A.; Valdez-Calderon, A.; Motilva, V.; García-Maurino, S.; et al. Absolute configuration of podophyllotoxin related lignans from Bursera fagaroides using vibrational circular dichroism. Phytochemistry 2011, 72, 2237-2243. [CrossRef] [PubMed]

79. Feliciano, A.S.; Medarde, M.; Lopez, J.L.; Puebla, P.; Miguel del Corral, J.M.; Barrer, A.F. Lignans from Juniperus thurifera. Phytochemistry 1989, 28, 2863-2866. [CrossRef]

80. Aynehchi, Y. Desoxypodophyllotoxin, the cytotoxic principle of Callitris columellaris F. Muell. J. Pharm. Sci. 1971, 60, 121-122. [CrossRef] [PubMed]

81. Van, U.W.; Pras, N.; Vossebeld, E.M.; Mol, J.N.; Malingre, T.M. Production of 5-methoxypodophyllotoxin in cell suspension cultures of Linum flavum L. Tissue Organ Cult. 1990, 20, 81-87.

82. Kier, L.B.; Fitzgerald, D.B.; Burgett, S. Isolation of podophyllotoxin from Callitrus drummondii. J. Pharm. Sci. 1963, 52, 502-503. [PubMed]

83. Hartwell, J.L.; Johnson, J.M.; Fitzgerald, D.B.; Belkin, M. Podophyllotoxin from Juniperus species; savinin. JACS 1953, 75, 235-236. [CrossRef]

84. Muranaka, T.; Miyata, M.; Ito, K.; Tachibana, S. Production of podophyllotoxin in Juniperus chinensis callus cultures treated with oligosaccharides and a biogenetic precursor in honour of Professor GH Neil towers 75th birthday. Phytochemistry 1998, 49, 491-496. [CrossRef]

85. Chang, L.C.; Song, L.L.; Park, E.J.; Luyengi, L.; Lee, K.J.; Farnsworth, N.R.; Pezzuto, J.M.; Kinghorn, A.D. Bioactive constituents of Thuja occidentalis. J. Nat. Prod. 2000, 63, 1235-1238. [CrossRef] [PubMed]

86. Mikac, S.; Markulin, L.; Drouet, S.; Corbin, C.; Tungmunnithum, D.; Kiani, R.; Kabra, A.; Abbasi, B.H.; Renouard, S.; Bhambra, A.; et al. Bioproduction of Podophyllotoxin and Related Aryltretralin-Lignans in Hairy Root Cultures of Linum Flavum L. Plant Cell Tissue Differ. Second. Metab. Fundam. Appl. 2021, 503-540. [CrossRef] 
87. Cantrell, C.L.; Zheljazkov, V.D.; Osbrink, W.L.; Castro, A.; Maddox, V.; Craker, L.E.; Astatkie, T. Podophyllotoxin and essential oil profile of Juniperus and related species. Ind. Crop. Prod. 2013, 43, 668-676. [CrossRef]

88. Och, M.; Och, A.; Ciesla, L.; Kubrak, T.; Pecio, L.; Stochmal, A.; Kocki, J.; Bogucka-Kocka, A. Study of cytotoxic activity, podophyllotoxin, and deoxypodophyllotoxin content in selected Juniperus species cultivated in Poland. Pharm. Biol. 2015, 53, 831-837. [CrossRef] [PubMed]

89. Renouard, S.; Corbin, C.; Colas, C.; Fidel, T.; Lopez, T.; Leclerc, E.A.; Hendrawati, O.; Falguieres, A.; Doussot, J.; Ferroud, C.; et al. Aerial parts of Callitris species as a rich source of deoxypodophyllotoxin. Ind. Crop. Prod. 2015, 63, 53-57. [CrossRef]

90. Wanner, J.; Jirovetz, L.; Schmidt, E. Callitris intratropica RT Baker \& HG Smith as a novel rich source of deoxypodophyllotoxin. Curr. Bioact. Compd. 2015, 11, 73-77.

91. Doussot, J.; Mathieu, V.; Colas, C.; Molinie, R.; Corbin, C.; Montguillon, J.; Banuls, L.M.Y.; Renouard, S.; Lamblin, F.; Dupre, P.; et al. Investigation of the lignan content in extracts from Linum, Callitris and Juniperus species in relation to their in vitro antiproliferative activities. Planta Med. 2017, 234, 574-581. [CrossRef] [PubMed]

92. Kasparova, M.; Martin, J.; Tu, A.L.; Spilkov, A.J. Production of podophyllotoxin by plant tissue cultures of Juniperus virginiana. Nat. Prod. Commun. 2017, 12, 101-103. [PubMed]

93. Broomhead, A.J.; Dewick, P.M. Aryltetralin lignans from Linum flavum and Linum capitatum. Phytochemistry 1990, 29, 3839-3844. [CrossRef]

94. Smollny, T.; Wichers, H.; De Rijk, T.; Van Zwam, A.; Shasavari, A.; Alfermann, A.W. Formation of lignans in suspension cultures of Linum album. Planta Med. 1992, 58, 622-624. [CrossRef]

95. Kranz, K.; Petersen, M. $\beta$-Peltatin 6-O-methyltransferase from suspension cultures of Linum nodiflorum. Phytochemistry 2003, 64, 453-458. [CrossRef]

96. Kartal, M.; Konuklugil, B.; Indrayanto, G.; Alfermann, A.W. Comparison of different extraction methods for the determination of podophyllotoxin and 6-methoxypodophyllotoxin in Linum species. J. Pharm. Biomed. Anal. 2004, 35, 441-447. [CrossRef]

97. Vasilev, N.; Ionkova, I. Lignan accumulation in cell cultures of Linum strictum ssp. strictum L. Acta Pharm. 2004, 54, 347-351.

98. Mohagheghzadeh, A.; Gholami, A.; Soltani, M.; Hemmati, S.; Alfermann, W. Linum mucronatum: Organ to organ lignan variations. Z. Nat. C 2005, 60, 508-510. [CrossRef] [PubMed]

99. Van Furden, B.; Humburg, A.; Fuss, E. Influence of methyl jasmonate on podophyllotoxin and 6-methoxypodophyllotoxin accumulation in Linum album cell suspension cultures. Plant Cell Rep. 2005, 24, 312-317. [CrossRef] [PubMed]

100. Federolf, K.; Alfermann, A.W.; Fuss, E. Aryltetralin-lignan formation in two different cell suspension cultures of Linum album: Deoxypodophyllotoxin 6-hydroxylase, a key enzyme for the formation of 6-methoxypodophyllotoxin. Phytochemistry 2007, 68, 1397-1406. [CrossRef] [PubMed]

101. Baldi, A.; Jain, A.; Gupta, N.; Srivastava, A.K.; Bisaria, V.S. Co-culture of arbuscular mycorrhiza-like fungi (Piriformospora indica and Sebacina vermifera) with plant cells of Linum album for enhanced production of podophyllotoxins: A first report. Biotechnol. Lett. 2008, 30, 1671-1677. [CrossRef]

102. Lautie, E.; Quintero, R.; Fliniaux, M.A.; Villarreal, M.L. Selection methodology with scoring system: Application to Mexican plants producing podophyllotoxin related lignans. J. Ethnopharmacol. 2008, 120, 402-412. [CrossRef]

103. Vasilev, N.; Ebel, R.; Edrada, R.A.; Fuss, E.; Alfermann, A.W.; Ionkova, I.; Petrova, A.; Repplinger, M.; Schmidt, T.J. Metabolic profiling of lignan variability in Linum species of section Syllinum native to Bulgaria. Planta Med. 2008, 74, 273-280. [CrossRef]

104. Samadi, A.; Jafari, M.; Nejhad, N.M.; Hossenian, F. Podophyllotoxin and 6-methoxy podophyllotoxin production in hairy root cultures of Liunm mucronatum ssp. mucronatum. Pharmacogn. Mag. 2014, 10, 154. [CrossRef]

105. Sasheva, P.; Ionkova, I. Podophyllotoxin production by cell cultures of Linum thracicum ssp. thracicum Degen elicited with methyl jasmonate and salicylic acid. Comptes Rendus Acad. Bulg. Sci. 2015, 68, 883-889.

106. Esfandiari, M.; Sharifi, M.; Mohamadyar-Toupkanlou, F.; Hanaee-Ahwaz, H.; Yousefzadi, M.; Jafari, A.; Hosseinzadeh, S.; Soleimani, M. Optimization of cell/tissue culture of Linum persicum for production of lignans derivatives including Podophyllotoxin. Tissue Organ Cult. 2018, 133, 51-61. [CrossRef]

107. Lalaleo, L.; Testillano, P.; Risueno, M.C.; Cusido, R.M.; Palazon, J.; Alcazar, R.; Bonfill, M. Effect of in vitro morphogenesis on the production of podophyllotoxin derivatives in callus cultures of Linum album. J. Plant Physiol. 2018, 228, 47-58. [CrossRef] [PubMed]

108. Kamal, A.; Ali-Hussaini, S.M.; Rahim, A.; Riyaz, S. Podophyllotoxinderivatives: A patent review (2012-2014). Expert Opin. Ther. Pat. 2015, 25, 1025-1034. [CrossRef] [PubMed]

109. Zia-Ul-Haq, M. Historical and Introductory Aspects of Carotenoids. In Carotenoids: Structure and Function in the Human Body; Zia-Ul-Haq, M., Dewanjee, S., Riaz, M., Eds.; Springer: Cham, Switzerland, 2021; pp. 1-42.

110. Puri, S.C.; Nazir, A.; Chawla, R.; Arora, R.; Riyaz-ul-Hasan, S.; Amna, T.; Ahmed, B.; Verma, V.; Singh, S.; Sagar, R.; et al. The endophytic fungus Trametes hirsuta as a novel alternative source of podophyllotoxin and related aryltetralin ligans. J. Biotechnol. 2006, 122, 494-510. [CrossRef]

111. Kour, A.; Shawl, A.S.; Rehman, S.; Sultan, P.; Qazi, P.H.; Suden, P.; Khajuria, R.K.; Verma, V. Isolation and identification of an endophytic strain of Fusarium oxysporum producing podophyllotoxin from Juniperus recurva. World J. Microbiol. Biotechnol. 2008, 24, 1115-1121. [CrossRef]

112. Cao, L.; Huang, J.; Li, J. Fermentation conditions of Sinopodophyllum hexandrum endophytic fungus on production of podophyllotoxin. Food Ferment. Ind. 2007, 33, 28-32. 
113. Huang, J.X.; Zhang, J.; Zhang, X.R.; Zhang, K.; Zhang, X.; He, X.R. Mucor fragilis as a novel source of the key pharmaceutical agents podophyllotoxin and kaempferol. Pharm. Biol. 2014, 52, 1237-1243. [CrossRef] [PubMed]

114. Nadeem, M. Fusarium solani, P1, a new endophytic podophyllotoxin-producing fungus from roots of Podophyllum hexandrum. Afr. J. Microbiol. Res. 2012, 6, 2493-2499.

115. Porter, J.; Eyberger, A.L.; Dondapati, R. Endophyte Fungal Isolates from Podophllum peltatum Produce Podophyllotoxin J. Nat. Prod. 2006, 69, 1121-1124.

116. Kusari, S.; Zuhlke, S.; Spiteller, M. Chemometric Evaluation of the Anti-cancer Pro-drug Podophyllotoxin and Potential Therapeutic Analogues in Juniperus and Podophyllum Species. Phytochem. Anal. 2011, 22, 128-143. [CrossRef] [PubMed]

117. Kusari, S.; Lamshoft, M.; Spiteller, M. Aspergillus fumigatus, an endophytic fungus from Juniperus communis L. Horstmann as a novel source of the anticancer pro-drug deoxypodophyllotoxin. J. Appl. Microbiol. 2009, 107, 1019-1030. [CrossRef] [PubMed]

118. Wang, T.; Ma, Y.X.; Ye, Y.H.; Zheng, H.M.; Zhang, B.W.; Zhang, E.H. Screening and identification of endophytic fungi producing podophyllotoxin compounds in Sinopodophyllum hexandrum stems. Chin. J. Exp. Trad. Med. 2017, 18, 493-532.

119. Tan, X.; Zhou, Y.; Zhou, X.; Xia, X.; Wei, Y.; He, L.; Tang, H.; Yu, L. Diversity and bioactive potential of culturable fungal endophytes of Dysosma versipellis; a rare medicinal plant endemic to China. Sci. Rep. 2018, 8, 1-9. [CrossRef] [PubMed]

120. Guo, S.; Jiang, B.; Su, Y.; Liu, S.; Zhang, L. Podophyllotoxin and its analogues from the endophytic fungi derived from Dysosma veitchii. Biotechnology 2004, 14, 55-57.

121. Zeng, S.; Shao, H.; Zhang, L. An endophytic fungus producing a substance analogous to podophyllotoxin isolated from Diphylleia sinensis. J. Microbiol. 2004, 24, 1-2.

122. Yang, X.; Guo, S.; Zhang, L.; Shao, H. Select of producing podophyllotoxin endophytic fungi from podophyllin plant. Nat. Prod. Res. Dev. 2003, 15, 419-422.

123. Yousefzadi, M.; Sharifi, M.; Behmanesh, M.; Ghasempour, A.; Moyano, E.; Palazon, J. The effect of light on gene expression and podophyllotoxin biosynthesis in Linum album cell culture. Plant Physiol. Biochem. 2012, 56, 41-46. [CrossRef] [PubMed]

124. Yang, D.L.; Sun, P.; Li, M.F. Chilling temperature stimulates growth, gene over-expression and podophyllotoxin biosynthesis in Podophyllum hexandrum Royle. Plant Physiol. Biochem. 2016, 9428, 30231-30235. [CrossRef]

125. Chattopadhyay, S.; Mehra, R.S.; Srivastava, A.K.; Bhojwani, S.S.; Bisaria, V.S. Effect of major nutrients on podophyllotoxin production in Podophyllum hexandrum suspension cultures. Appl. Microbiol. Biotechnol. 2003, 60, 541-546. [CrossRef] [PubMed]

126. Li, M.F.; Li, W.; Yang, D.L.; Zhou, L.L.; Li, T.T.; Su, X.M. Relationship between podophyllotoxin accumulation and soil nutrients and the influence of $\mathrm{Fe}^{2+}$ and $\mathrm{Mn}^{2+}$ on podophyllotoxin biosynthesis in Podophyllum hexandrum tissue culture. Plant Physiol. Biochem. 2013, 71, 96-102. [CrossRef]

127. Alam, M.A.; Naik, P.K. Impact of Soil Nutrients and Environmental Factors on Podophyllotoxin Content among 28 Populations of Podophyllum Hexandrum. Commun. Soil Sci. Plant Anal. 2009, 40, 2485-2504. [CrossRef]

128. Xu, H.; Lv, M.; Tian, X. A review on hemisynthesis, biosynthesis, biological activities, mode of action, and structure-activity relationship of podophyllotoxins: 2003-2007. Curr. Med. Chem. 2009, 16, 327-349. [CrossRef] [PubMed]

129. Farkya, S.; Bisaria, V.S.; Srivastava, A.K. Biotechnological aspects of the production of the anticancer drug podophyllotoxin. Appl. Microbiol. Biotech. 2004, 65, 504-519. [CrossRef] [PubMed]

130. Brewer, C.F.; Loike, J.D.; Horwitz, S.B.; Sternlicht, H.; Gensler, W.J. Conformational analysis of podophyllotoxin and its congeners. Structure-activity relationship in microtubule assembly. J. Med. Chem. 1979, 22, 215-221. [CrossRef] [PubMed]

131. Zia-Ul-Haq, M. Past, Present and Future of Carotenoids Research. In Carotenoids: Structure and Function in the Human Body; Zia-Ul-Haq, M., Dewanjee, S., Riaz, M., Eds.; Springer: Cham, Switzerland, 2021; pp. 827-854.

132. Desbene, S.; Giorgi-Renault, S. Drugs that inhibit tubulin polymerization: The particular case of podophyllotoxin and analogues. Curr. Med. Chem. Anti Cancer Agents 2002, 2, 71-90. [CrossRef]

133. Hu, C.; Xu, D.; Du, W.; Qian, S.; Wang, L.; Lou, J.; He, Q.; Yang, B.; Hu, Y. Novel 4 beta-anilino-podophyllotoxin derivatives: Design synthesis and biological evaluation as potent DNA-topoisomerase II poisons and anti-MDR agents. Mol. Biosyst. 2010, 6, 410-420. [CrossRef]

134. Ming-Jen, C.; Ming, D.; Hing, Y.; Sung, Y.; Jih, J.; Hsun, S.; Yueh, H.; Gwo, F.; Ih, S. A New Benzenoid Derivative from an Endophytic Fungus in Peperomia sui. Chem. Nat. Compd. 2018, 54, 625-627.

135. Markkanen, T.; Makinen, M.L.; Nikoskelainen, J.; Ruohonen, J.; Nieminen, K.; Jokinen, P.O.; Rannio, R.; Hirvonen, T. Biological activities of lignans. Drugs Exp. Clin. Res. 1981, 7, 691.

136. Fife, K.H. New treatments for genital warts less than ideal: Abstract and commentary. JAMA 1998, 279, $2003-2004$. [CrossRef] [PubMed]

137. Sudo, K.; Konno, K.; Shigeta, S.; Yokota, T. Inhibitory Effects of Podophyllotoxin Derivatives on Herpes Simplex Virus Replication. Antivir. Chem. Chemother. 1998, 9, 263-267. [CrossRef] [PubMed]

138. MacRae, W.D.; Hudson, J.B.; Towers, G.H. The antiviral action of lignans. Planta Med. 1989, 55, 531-535. [CrossRef] [PubMed]

139. Syed, T.A.; Cheema, K.M.; Khayyami, M.; Ahmad, S.A.; Ahmad, S.H.; Ahmad, S. Human leukocyte interferon-alpha versus podophyllotoxin in cream for the treatment of genital warts in males. A placebo-controlled, double-blind, comparative study. Dermatology 1995, 191, 129. [CrossRef]

140. Beautner, K.R. Podophyllotoxin in the treatment of genital warts. In EP Eischman (edn) Sexually Transmitted Diseases. Adv. Treat. 1996, 24, 122-232. 
141. Zhao, W.; Cong, Y.; Li, H.M.; Li, S.; Shen, Y.; Qi, Q.; Zhang, Y.; Li, Y.Z.; Tang, Y.J. Challenges and potential for improving the druggability of podophyllotoxin-derived drugs in cancer chemotherapy. Nat. Prod. Rep. 2021, 38, 470-488. [CrossRef]

142. Zhang, J.; Liu, Y.Q.; Yang, L.; Feng, G. Podophyllotoxin Derivatives Show Activity against Brontispa Longissima Larvae. Nat. Prod. Commun. 2010, 5, 1247-1250. [CrossRef] [PubMed]

143. Leander, K.; Rosen, B. Medicinal Uses for Podophyllotoxin. U.S. Patent 4,788,216, 29 November 1988. Available online: https://patents.google.com/patent/US4788216A/en (accessed on 15 February 2021).

144. Lerndal, T.; Svensson, B. A clinical study of CPH 82 vs. methotrexate in early rheumatoid arthritis. Rheumatology 2000, 39 , 316. [CrossRef] [PubMed]

145. Gordaliza, M.; Castro, M.A.; Miguel del Corra, J.M.; Feliciano, S.A. Antitumor Properties of Podophyllotoxin and Related Compounds. Curr. Pharm. Des. 2000, 6, 1811-1839. [CrossRef]

146. Hensel, A.; Bauer, R.; Heinrich, M.; Spiegler, V.; Kayser, O.; Hempel, G.; Kraft, K. Challenges at the Time of COVID-19: Opportunities and innovations in the Antivirals from Nature. Planta Med. 2020, 86, 659-664. [CrossRef]

147. Thanh, V.T.T.; Pham, V.C.; Mai, H.D.T.; Litaudon, M.; Gueritte, F.; Retailleau, P.; Nguyen, V.H.; Chau, V.M. Cytotoxic Lignans from Fruits of Cleistanthus indochinensis: Synthesis of Cleistantoxin Derivatives. J. Nat. Prod. 2012, 75, 1578-1583. [CrossRef] [PubMed]

148. Nanjundaswamy, N.; Satishi, S.; Lokanatha Rai, K.M.; Shashikanth, S.; Raveesha, K.A. Antibacterial Activity of Synthetic Precursors of Podophyllotoxin. Int. J. Biomed. Sci. 2007, 3, 112-115. [PubMed]

149. Dombernowsky, P.; Nissen, N.I. Schedule dependency of the antileukemic activity of the podophyllotoxin-derivative VP 16-213 (NSC-141540) in L1210 leukemia. Acta Physiol. Microbiol. Scand. Sec. A Path. 1973, 81, 715-724. [CrossRef]

150. Liu, Y.Q.; Feng, G.; Yang, L.; Zhang, J.; Li, H.Y. Podophyllotoxin-derived insecticidal agents: Part XIII-Evaluation of insecticidal activity of podophyllotoxin derivatives against Brontispa longissima. Nat. Prod. Res. 2010, 25, 1570-1576. [CrossRef] [PubMed]

151. Wang, J.; Long, L.; Chen, Y. Design, synthesis and antineoplastic activity of novel hybrids of podophyllotoxin and indirubin against human leukemia cancer cells as multifunctional anti-MDR agents. Bioorg. Med. Chem. Lett. 2018, 28, 1817-1824. [CrossRef] [PubMed]

152. Yang, L.X. Podophyllotoxins Derivatives. U.S. Patent US-8158809-B2, 17 April 2012. Available online: https:/ / patents.google. com/patent/US8158809B2/en (accessed on 15 February 2021).

153. Larsson, O.; Axelson, M. New Use of Specific Cyclolignans. World Intellectual Property Organization W.O. Patent WO-02/102804A1, 19 June 2002. Available online: https:/ / patents.google.com/patent/WO2002102804A1/en (accessed on 15 February 2021).

154. Kerkar, B.; Potier, P. Novel Podophyllotoxin Derivatives, the Production. There of and the Use of the Same in Therapeutics. World Intellectual Property Organization W.O. Patent WO2003082875A3, 19 October 2003. Available online: https:/ / patents.google. com/patent/WO2003082875A3/en (accessed on 15 February 2021).

155. Zhang, Z.; Zhou, M.; Zhang, Y. Podophyllotoxin Derivative with 4-Position Nitrogen Substitution and Preparation Method and Application There of. U.S. Patent US-10639295-B2, 5 May 2020. Available online: https://patents.google.com/patent/US1063929 5B2/en (accessed on 15 February 2021).

156. Kamal, A.; Reddy, V.G.; Subbarao, A.V.; Riyaz, S.; Nayak, V.L.; Taj, S. 4Beta-Amidotriazole Linked Podophyllotoxin Derivatives as Potential Anticancer Agents. U.S. Patent US-2020123171-A1, 28 May 2020. Available online: https:/ / patents.google.com/patent/ US20200123171A1/en (accessed on 15 February 2021).

157. Quirion, J.; Deliencourt-Godefroy, G.C.; Audouard, C. Gem-Difluorinated C-Glycoide Compounds Derived from Podophyllotoxin, Their Preparation and Their Application. U.S. Patent US8236935B2, 7 August 2012. Available online: https://patents.google. com/patent/US8236935B2/en (accessed on 15 February 2021).

158. Tang, Y.; Zhao, W. 4-Sulfur Substituted Podophyllotoxin Derivative and Preparation Method There of and Use There of. U.S. Patent US20200216462A1, 9 July 2020. Available online: https:/ / patents.google.com/patent/US20200216462A1/en (accessed on 15 February 2021).

159. Tang, Y.; Li, J.; Zhao, W.; Li, H. Sulfur-Substituted Podophyllotoxin Derivative, Synthesis Method There of, and Use There of. U.S. Patent US9828386B2, 28 November 2017. Available online: https:/ / patents.google.com/patent/US9828386B2/en (accessed on 15 February 2021).

160. Patents Lens Database. Available online: https://www.lens.org/lens/search/patent/list?q=Podophyllotoxin\&preview=true (accessed on 15 February 2021).

161. Google Patents Database. Available online: https://patents.google.com/?q=Podophyllotoxin\&num=100\&oq=Podophyllotoxin (accessed on 15 February 2021). 